\title{
ANALYTICAL STUDY OF THE PATTERN OF CONSUMPTION OF ANIMAL PROTEIN SOURCES IN THE ARAB REPUBLIC OF EGYPT
}

\author{
WAEL AZAB AHMED and MONA MAHMOUD MOHAMED MEKKAWY
}

\author{
Agric. Economics Research Institute, ARC, Giza
}

(Manuscript received 18 April 2016)

\begin{abstract}
nimal protein is an essential element that helps the body grow and compensate damages resulting from nutritional imbalances. Average per capita share of animal protein is one of the most important indicators for population growth and advancement. Main sources of animal protein addressed in this research include red meat, white meat, fish, eggs and dairy products. And despite the fact that consumers prefer red meat, there exist other alternative sources that are cheaper and in the same time provide an individual with most of the daily needs of animal protein at the level of urban and rural areas. The research aimed to identify the current state of national production and consumption of animal protein from different sources; study the evolution of average per capita, surplus, shortage, and rate of selfsufficiency in animal protein; study the structure of consumption expenditure, and derive the elasticity of expenditure on animal protein components for rural and urban area over the period (2000-2013). In addition, the research studied the structure of consumption expenditure for the mentioned sources according to price levels, and estimated the price elasticity for animal protein group over the same period.
\end{abstract}

The research reached the following results: The production levels of red meat, white meat, milk, eggs, and fish have been increasing at rates estimated at $0.66 \%, 1.27 \%, 2.81 \%$, $4,44 \%$, and 5,46\%, respectively, which proved statistically significant at 0.01 level, except for red and white meat. The annual pricing for red meat, white meat, milk, eggs, and fish have been increasing at rates estimated at $1.54 \%, 1.62 \%, 1.28 \%, 5.01 \%$, and $3.86 \%$, respectively, which proved statistically significant, except for red and white meat. The average per capita share of animal protein has also been increasing on annual basis. However, such increase proved statistically significant only for fish, which can be due to fluctuations in average per capita share over the study period. With regard to the surplus and shortage of animal protein, results showed a shortage in red meat estimated at $4.4 \%$ per annum; a shortage in milk estimated at $8.7 \%$ per annum; and a shortage in fish estimated at $10.8 \%$ per annum during the study period. Results also showed a surplus in eggs and white meat at annual rates estimated at $1.42 \%$ and $40.24 \%$, respectively. The results regarding self-sufficiency in animal protein sources showed declines in self-sufficiency rates in red meat, white meat, and eggs estimated at $0.99 \%, 0.31 \%$, and $0.42 \%$, respectively. By contrast, results showed increases in selfsufficiency rates of milk and fish, estimated at $1.62 \%$ and $1.65 \%$, respectively. However, declines in red meat and eggs did not prove statistically significant, whilst proved significant for white meat, milk, and fish.

The results of estimating the elasticity of demand for meat at the level of rural and urban areas, and country level over the study period showed that it amounted to $0.59,0.66$, and 0.61 , respectively; whilst amounted to $0.85,0.83$, and 0.87 for fish, respectively; and amounted to $0.57,0.56$, and 0.49 for milk and eggs, respectively.

The results of estimating the price elasticity of demand for the main sources of animal protein, i.e., buffalo and cow meat, sheep, domestic chicken, white chicken, tilapia, mullet, and catfish, showed that it reached $0.5,0.44,0.55,015,0.06,0.05$, and 0.05 , respectively. 


\title{
دراسة تحليلية للنمط الاستهلاكى لمصادر البروتين الحيوانى فى جمهورية مصر العربية
}

\author{
وائل عزب احمد1 1 و منى محمود محمد مكاوى2 \\ 1. قسم بحوث تتمية الدجتمع الريفى - معطد بحوث الاقتصاد الزراعى - مركز البحوث الزراعية

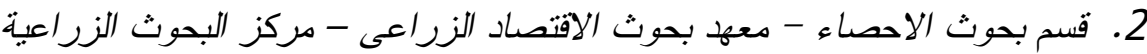 \\ الملخص \\ استهدف البحث التعرف على الوضع الراهن للانتاج والأستهلالك

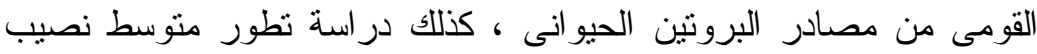

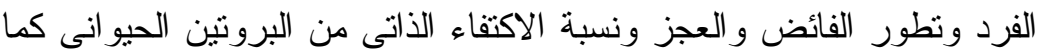

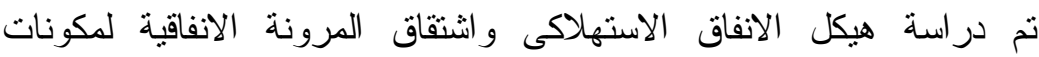

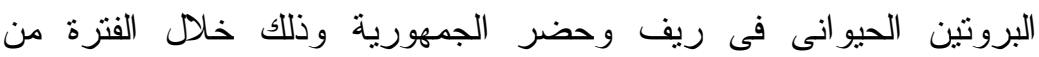 \\ (2000-2013)، كما تم دراسة هيكل الانفاق الأستهلاكى لهذه المصادر وفقاب ونات

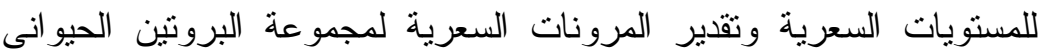

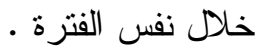

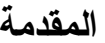

يعتبر البروتين الحيوانى احد المكونات الاساسية فى الوجبة الغذائية للأنسان ، ويعتبر

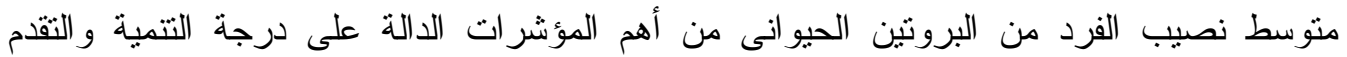

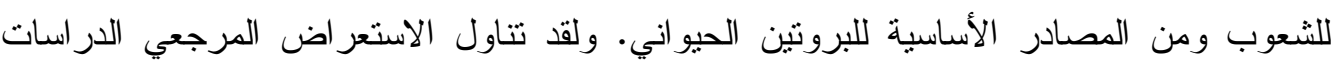
النالية :-

حيث استعر اض عبد النبي (1) الوضع الر اهن للإنتاج والاستهلالك القومي للحوم الحمراء

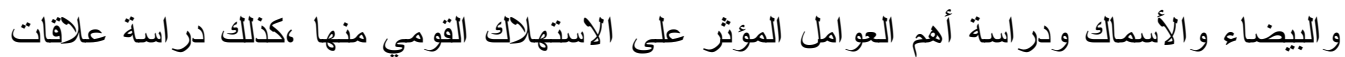

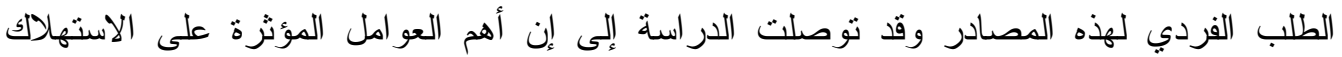

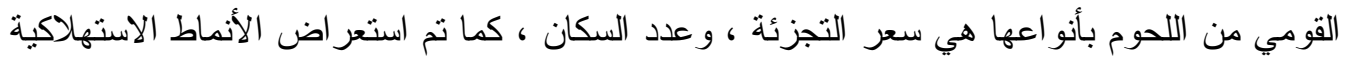

$$
\text { المختلفة لهصادر البروتين في كل من الريف و الحضر . }
$$

كما استعرض شوقي (2) الوضع الراهن لإنتاج واستهلالك اللحوم الحمراء والبيضاء

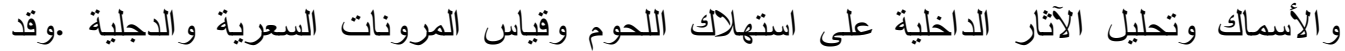
توصلت الدراسة إلى ضرورة تنمية الوعي الغذائي بهدف تغيير النمط الغذائي من اللحوم الطازجة التي تمتل اعلي نسبة إنفاق واعلي سعر وحدة بروتين إلى استهلالك الطيور و الدو اجن و الأسماك حيث

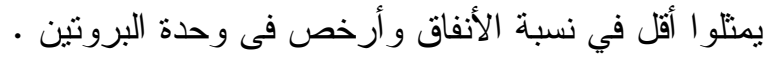

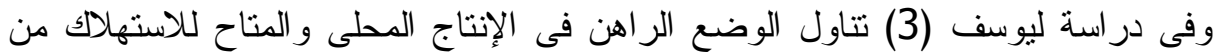
اللحوم الحمراء وقد توصلت الدراسة إلى أن الإنتاج المحلى بعجز عن تغطية الإنى الاحتياجات المحلية 
للسكان و أوصت الدراسة بضرورة زيادة الإنتاج المحلى من اللحوم من الحمراء باستتباط معدلات

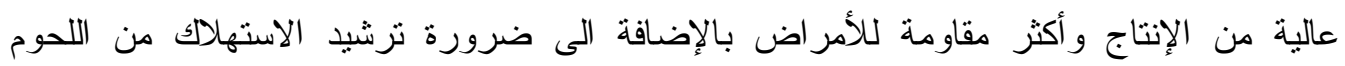

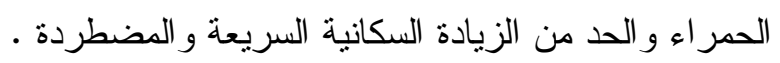

كما استهدفت دراسة مصطفى عبد ربة و آخرون(4) در اسة الوضع الرة الر اهن لإنتاج و استهلاكك

اللحوم الحمراء وتطورها في مصر كما استهدف البحث نقدير حجم الفجوة الغذائية من اللحوم الحمر اء ونسبة الاكتفاء الذاتي منها والثقدير الكمي لأثز أهم محددات الفجوة الغذائية من اللحوم الحمر اء وقد أوصت الدراسة بضرورة الاهتمام بقطاع الإنتاج الحيواني وتحسين زيادة إنتاجية

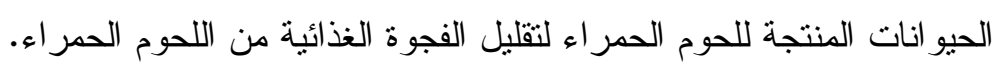

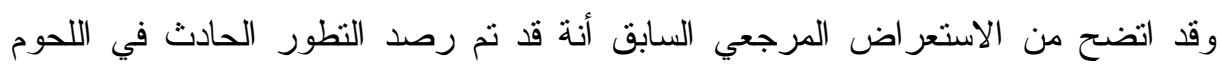
بأنو اعها سواء حمر اء أو بيضاء في حين لم تهتم بباقي مصادر البروتين الحيواني الأخرى مثل فئل

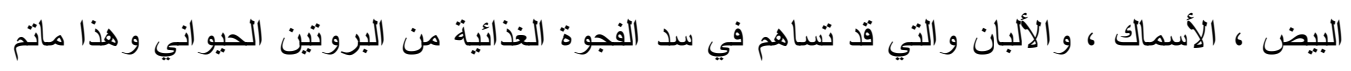

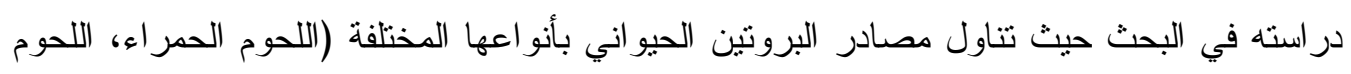

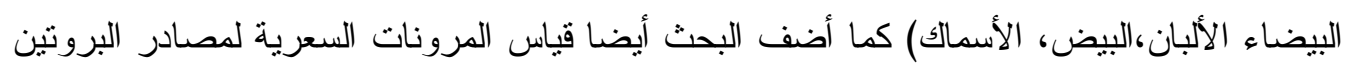
المختلفة ومتوسط نصيب الفرد منها وتطور الفائض و العجز ونسبة الاكتفاء الذاتي من البروتين

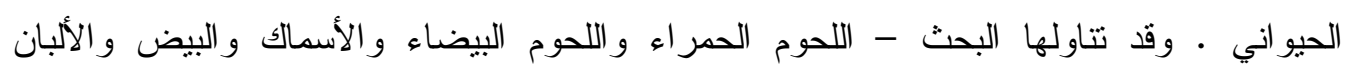

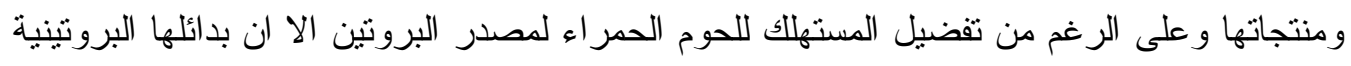

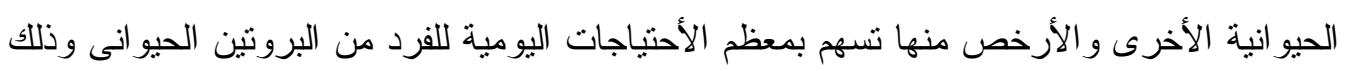
على مستوى الريف والحضر على السواء ،وتثير تقدير ات نشر ات الميز ان الغذائى ان نسبة الاكتفاء

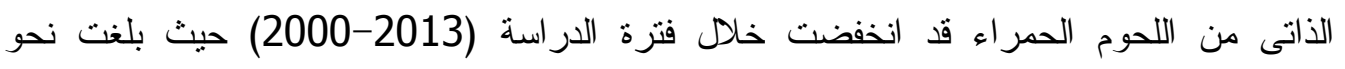

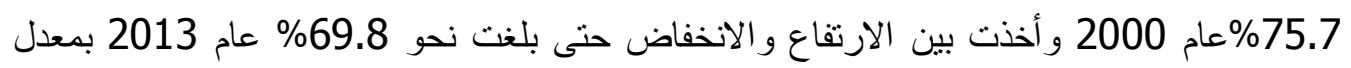
تتاقص بلغ نحو 7.79\% خلال الفترة (2013-2000)،كما بلغت نسبة الاكتفاء الذاتى من اللحوم

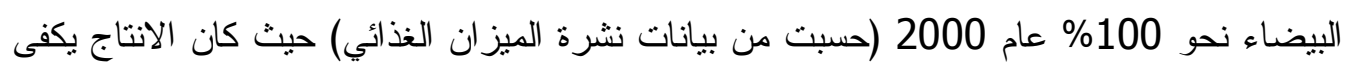

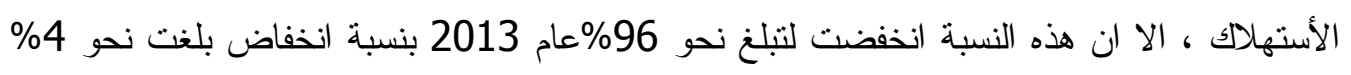

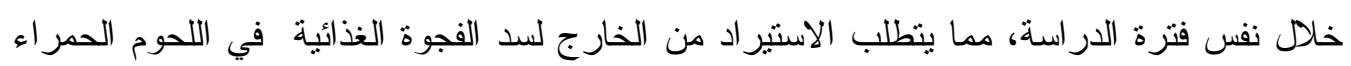

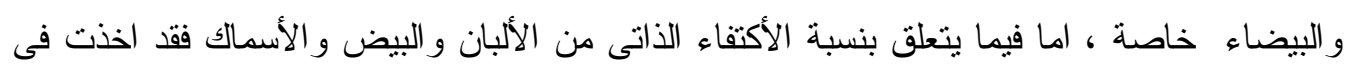

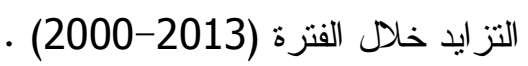

\section{مشكلة البحث}

تتمثل مشكلة البحث فى التزايد المستمر فى أعداد السكان مما يؤدى إلى عجز الأنتاج المحلى من

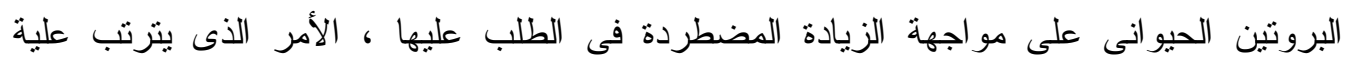

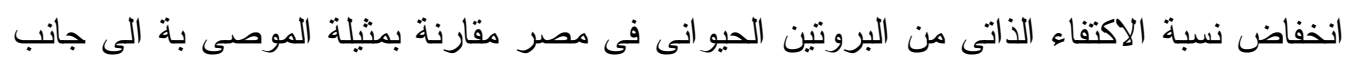

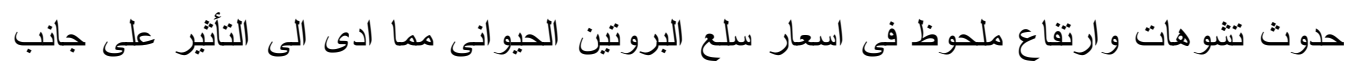

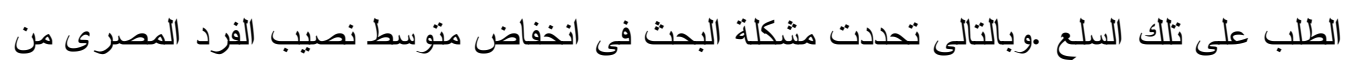




\section{هدف البحث \\ انطلاقا من مشكلة البحث فقد تحدد هدف البحث في التعرف على أسباب انخفاض متوسط نصيب \\ الفرد المصري من البرونين الحيو اني من خلال:- \\ 1- دراسة تطور كل من الانتاج والأستهلاك ومتوسط نصيب الفرد وحجم الفجوة الغذائية من

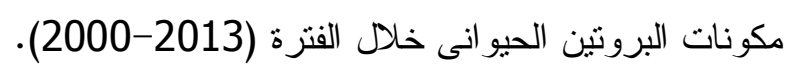

2- التعرف على هيكل الأنفاق الأستهلاكى لمصادر البروتين الحيو انى بريف وحضر الجمهورية

$$
\text { خلال الفترة (2013-2000). }
$$

3- التشوهات السعرية للحوم و الدو اجن

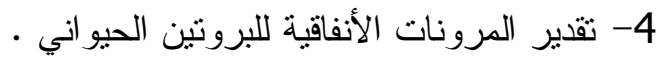

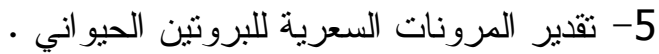

\section{الطريقة البحثية ومصادر البيانات}

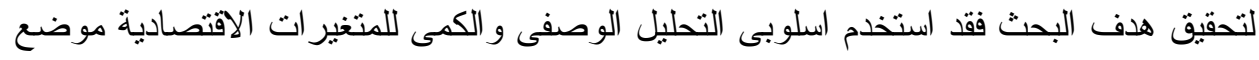
الدراسة وقد اعتمد البحث على البيانات الثانوية الصادرة من الجهات الرسمية كالجهاز المركزى

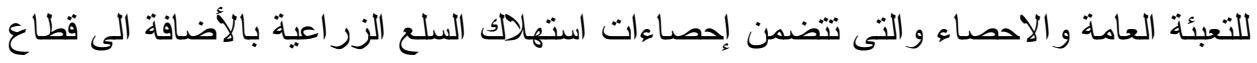
الثئون الافتصادية، بحث ميزانية الأسرة والنشر ات التى تصدر من قبل الجهات الأخرى و المعنية

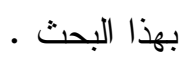

\section{النتائج والمناقشة}

$$
\text { أولاً : مكونات البروتين الحيوانى: }
$$

يتمثل الأنتاج المحلى من مصادر البروتين الحيو انى فى كل من اللحوم الحمر اءو والبيضاء

$$
\text { و الأسماك و البيض و الألبان }
$$

1: تطور الأتتاج الكلى من اللحوم الحمراء والبيضاء والألبان و البيض والأسماك.

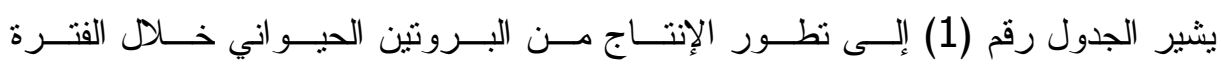

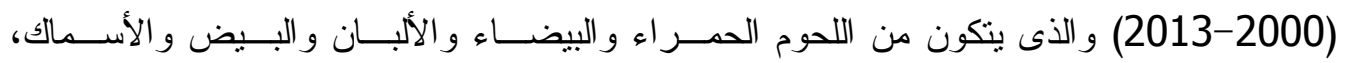

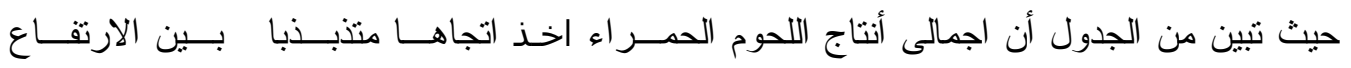

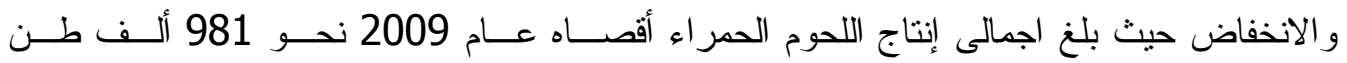

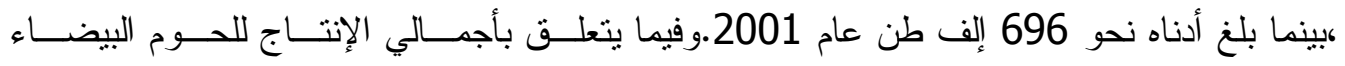

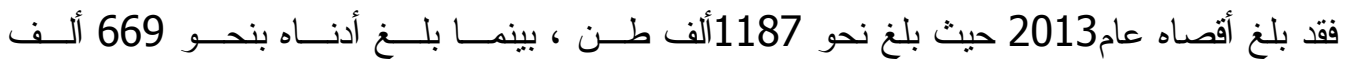

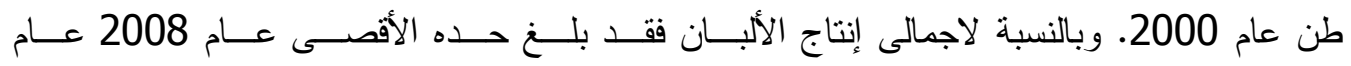

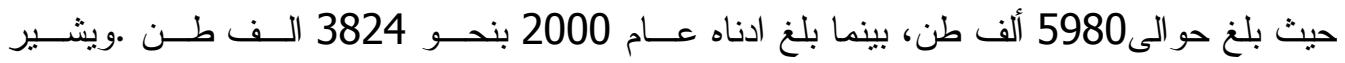

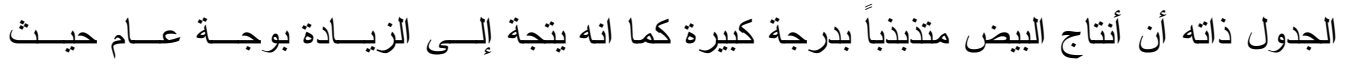

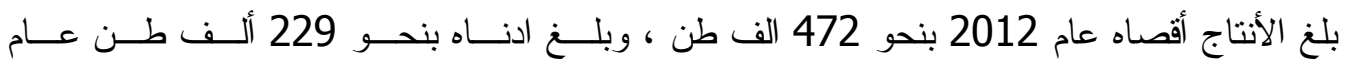

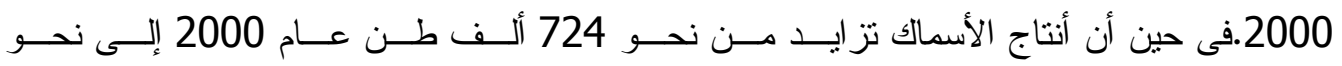
1454 ألف طن عام 2013 بتز ايد قدره 730 ألف طن ونسبة زيادة 100.8 100ن . 
بدارســـة الاتجــاه الزمنــى العــام خــالد الفتــرة (2013-2000) لانتـــاج اللحــوم

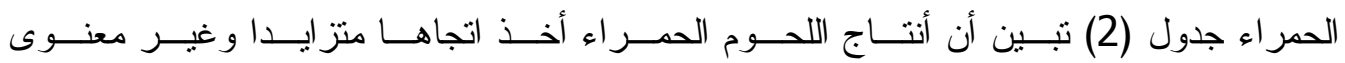

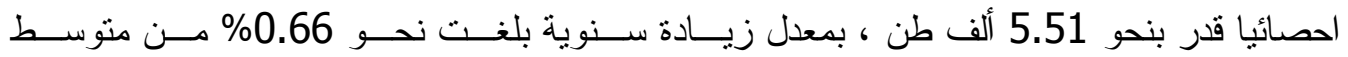

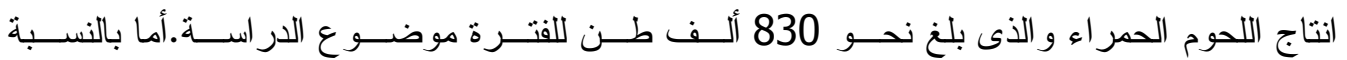

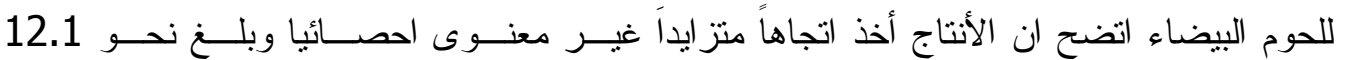

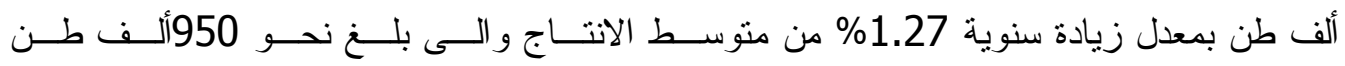

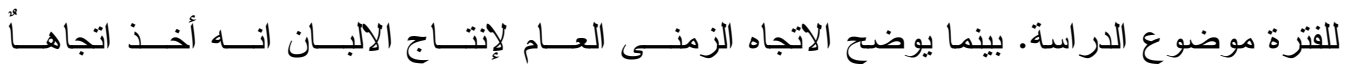

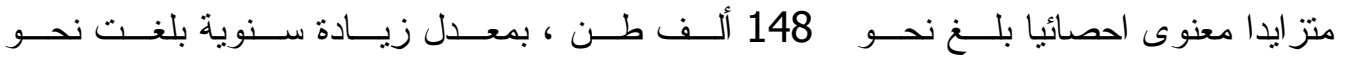

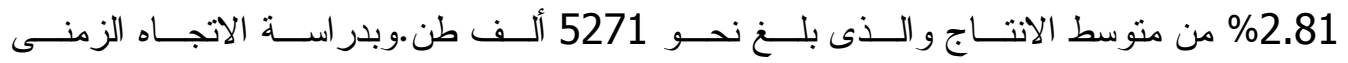

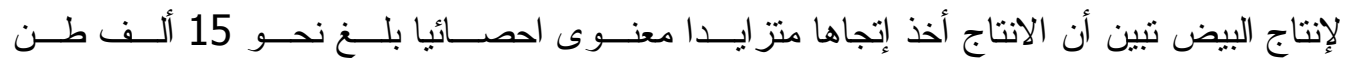

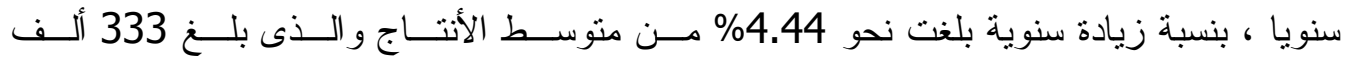

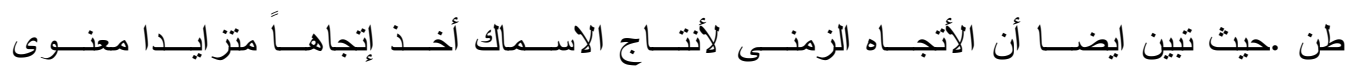

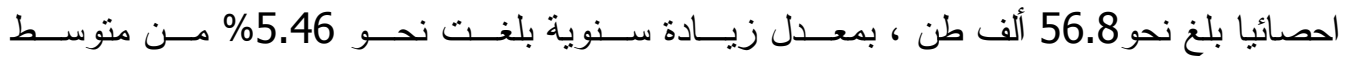

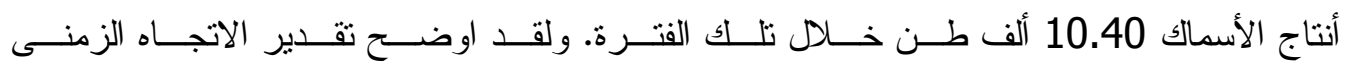

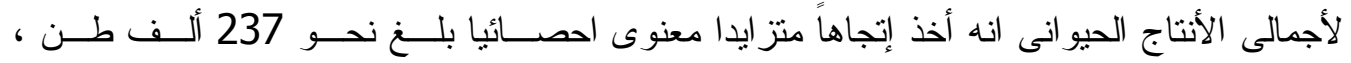

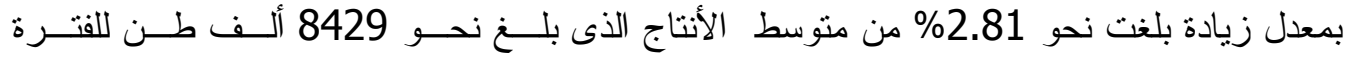
موضوع الدر اسة . جدول رقم ( 1 ) نطور الأنتاج الكلى من البروتين الحيو انى خلال الفترة (2013-2000) بالألف طن

\begin{tabular}{|c|c|c|c|c|c|}
\hline أنتاج الأسماك & انتاج البيض & أنتاج الألبان & أنتاج اللحوم & أنتاج اللحوم & \\
\hline 724 & 229 & 3824 & 669 & 705 & 2000 \\
\hline 772 & 271 & 3954 & 863 & 696 & 2001 \\
\hline 802 & 336 & 4210 & 1164 & 821 & 2002 \\
\hline 876 & 322 & 5280 & 1048 & 840 & 2003 \\
\hline 865 & 335 & 4682 & 983 & 818 & 2004 \\
\hline 889 & 270 & 5551 & 1018 & 855 & 2005 \\
\hline 971 & 244 & 5787 & 795 & 879 & 2006 \\
\hline 1008 & 279 & 5925 & 879 & 917 & 2007 \\
\hline 1068 & 356 & 5980 & 834 & 961 & 2008 \\
\hline 1093 & 333 & 5624 & 878 & 981 & 2009 \\
\hline 1305 & 398 & 5774 & 949 & 791 & 2010 \\
\hline 1362 & 410 & 5803 & 1001 & 787 & 2011 \\
\hline 1372 & 472 & 5849 & 1037 & 788 & 2012 \\
\hline 1454 & 471 & 5554 & 1187 & 780 & 2013 \\
\hline 1040.07 & 337.57 & 5271.21 & 950.35 & 829.92 & المتوسط \\
\hline
\end{tabular}

المصدر : وز ارة الزر اعة واستصلاح الأراضى ، قطاع الشئون الأقتصادية، نشرة الميز ان الغذائى - اعداد متقرقة 
جدول رقم (2) الاتجاه الزمنى لأنتاج اللحوم الحمر اء و البيضاء و الالبان و البيض و الاسماك خلال الفترة (2013- 2000)

\begin{tabular}{|c|c|c|c|c|c|c|}
\hline المغوية & $\mathbf{F}$ & التغير & $\mathbf{R}^{2}$ & $\mathbf{T}$ & المعادلة & البيان \\
\hline- & 0.97 & 0.66 & 0.075 & 0.99 & $Y 1=5.51+789 x$ & اللحوم الحمر اء \\
\hline - & 1.74 & 1.27 & 0.127 & 1.32 & $Y 2=860+12.1 x$ & اللحوم البيضـاء \\
\hline ** & 22.27 & 2.81 & 0.650 & 4.72 & $Y 3=4162+148 X$ & الألبان \\
\hline *** & 22.86 & 4.44 & 0.656 & 4.78 & $Y 4=225+15 X$ & البيض \\
\hline *** & 223.52 & 5.46 & 0.949 & 14.95 & $Y 5=614+56.8 X$ & الاسماك \\
\hline ** & 58.90 & 2.81 & 0.831 & 7.67 & $Y 6=6650+237 X$ & 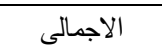 \\
\hline
\end{tabular}

المصدر : حسبت من بيانات جدول رقم (1).

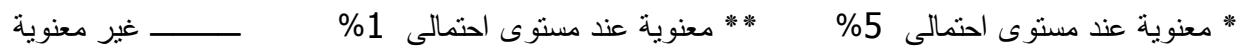

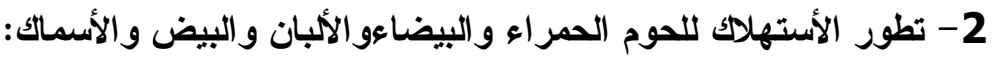

تعتبر معدلات استهلاك البروتين الحيوانى من المقاييس الأساسية لمستوى المعيشة ونتشير الإحصاءات إلى أن متوسط الاستهلاك من البروتين الحيو اني في تز ايد مستمر ،كما يتضح من الجدول

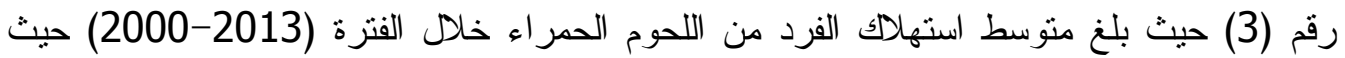
بلغ المنتوط الأدنى793عام 2001 بينما بلغ المتوسط الأقصى 1382 ألف طن عام 2007 بنسبة زيادة قدر بنحو 48\%، في حين بلغ أقصى استهلاك للحوم البيضاء عام 2013 بنحو 1237 ألف طن ، و أدنى استهلاك نحو 669 ألف طن عام 2000. بينما بلغ استهلاك الألبان أقصاه عام 2007 بنحو 6707 الف طن ، وبلغ أدناه بنحو 4961 ألف طن عام 2000 ـ ويشير الجدول ذاتة إلى أن استهلاك البيض بلغ أقصاه عام 2012 بنحو 416 الف طن ،وبلغ الاستهلاك أدناه بنحو 188 ألف بلف طن عام 2006 وهو ياخذ اتجاهاً متز ايدا بوجه عام .كما اوضح الجدول أن استهلاك الأسماك متذبذب حيث بلغ أقصاه عام 2012 بنحو 1518 الف طن ، و وأدناه بنحو 944 ألف طن عاحن عام 2002

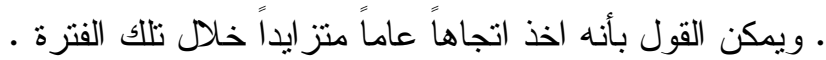
جدول رقم ( 3) تطور أستهلاك البروتين الحيو انى خلال الفترة (2013-2000) بالألف طن

\begin{tabular}{|c|c|c|c|c|c|}
\hline استهلاك الأسماك & استهلاك البيض & استهلاك الألبان & استهلاك اللحوم & استهلاك اللحوم & البيان \\
\hline 948 & 204 & 4961 & 669 & 931 & 2000 \\
\hline 1039 & 226 & 5198 & 860 & 793 & 2001 \\
\hline 944 & 274 & 5483 & 1161 & 960 & 2002 \\
\hline 1009 & 262 & 6601 & 1047 & 1019 & 2003 \\
\hline 958 & 274 & 5407 & 983 & 960 & 2004 \\
\hline 1003 & 221 & 6557 & 1016 & 1133 & 2005 \\
\hline 1100 & 188 & 6389 & 805 & 1312 & 2006 \\
\hline 1144 & 229 & 6707 & 882 & 1382 & 2007 \\
\hline 1082 & 287 & 6699 & 793 & 1176 & 2008 \\
\hline 1131 & 290 & 6093 & 898 & 1196 & 2009 \\
\hline 1398 & 354 & 6172 & 974 & 1052 & 2010 \\
\hline 1381 & 361 & 6337 & 1035 & 1033 & 2011 \\
\hline 1518 & 416 & 6248 & 1072 & 1052 & 2012 \\
\hline 1499 & 409 & 6117 & 1237 & 1118 & 2013 \\
\hline 1153.8 & 285.3 & 6069.2 & 959.4 & 1079.7 & متوسط الفترة \\
\hline
\end{tabular}

المصدر : وزارة الزر اعة واستصلاح الأر اضى ، قطاع الثئون الأقتصادية، نشرة الميز ان الغذائى - اعداد متفرقة 
وبتقدير معادلات الاتجاه الزمني العام بالجدول رقم (4) تبين إن الاستهلاك من اللحوم

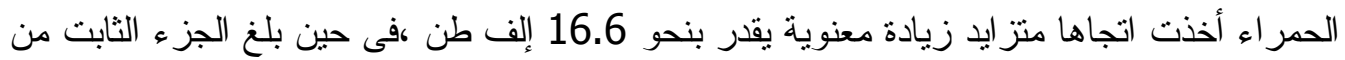
الاستهلاك فى حالة انعدام الدخل 955 الف طن خلال الفترة ومعدل الزيادة السنوي بلغ 1.54\% من متوسط الاستهلاك الكلى للحوم الحمر اء الذي يقدر بنحو 1079 ألف طن. وتوضح معادلة الاتجاه

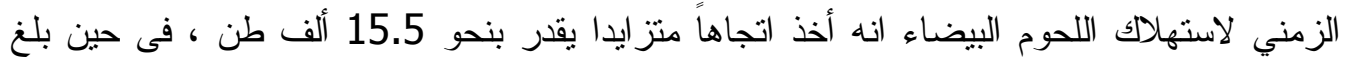
الجزء الثابت من الاستهلاك فى حالة انعدام الدخل نحو 843 الف طن خلال الفترة ونسبة زيادة سنوية بلغت 62\% من منوسط الاستهلاك البالغ نحو 959.4 ألف طن خلال تلك الفترة. بينما

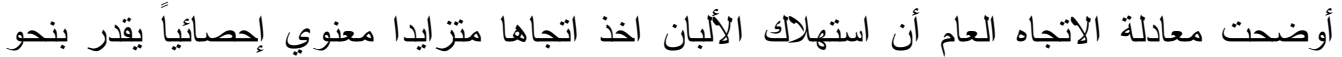
77.9 الف طن فى حين بلغ الجزء الثابت من الاستهلاك فى حالة انعدام الدخل نحو 5485 الف طن خلال الفترة ،ومعدل زيادة سنوية بلغت 1.28\% من متوسط الاستهلاك البالغ نحو 6069 ألف طن خلا نلك الفترة. وبالنسبة لاستهلاك البيض فقد أوضحت معادلة الاتجاه الزمنى العام أن الاستهلاك

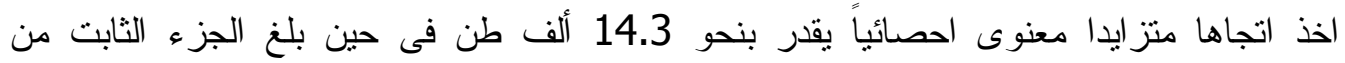
الاستهلاك فى حالة انعدام الدخل نحو 178 الف طن خلال الفترة ، ومعدل زيادة سنوية بلغت 5.02\% من متوسط الاستهلاك الذى يبلغ نحو 285 ألف طن خلال نلك الفترة. وتبين ايضا معادلة الاتجاه الزمنى العام لاستهلاك الاسماك ان هناك اتجاهاً متز ايدا معنوى احصائيا يقدر بنحو 44.5

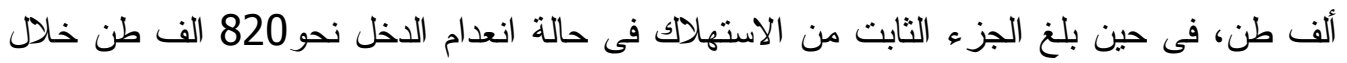

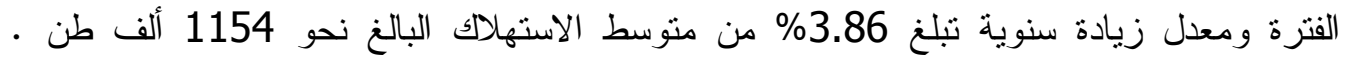

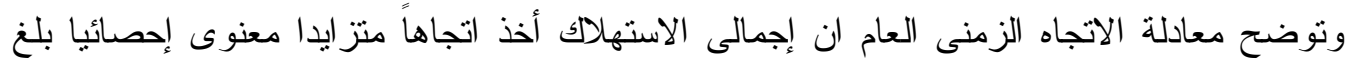

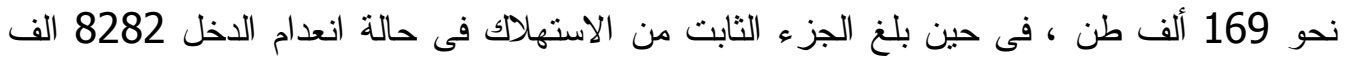
طن خلا الفترة ومعدل زيادة سنوية بلغت 1.77\% من منوسط الاستهلاك الكلى البالغ نحو 9548 ألف طن للفترة موضع الدر اسة .

\begin{tabular}{|c|c|c|c|c|c|c|}
\hline المغنوية & $\mathrm{F}$ & التغير \% & $\mathbf{R}^{2}$ & $\mathbf{T}$ & المعادلة الم & البيان ان \\
\hline- & 3.00 & 1.54 & 0.200 & 1.73 & $Y i=955+16.6 X$ & اللحوم الحمر اء \\
\hline- & 2.64 & 1.62 & 0.180 & 1.62 & $Y i=843+15.5 X$ & اللحوم البيضـاء \\
\hline * & 5.65 & 1.28 & 0.320 & 2.38 & $Y i=5485+77.9 X$ & الألبان ال \\
\hline ** & 23.11 & 5.02 & 0.658 & 4.81 & $Y i=178+14.3 X$ & البيض \\
\hline *** & 52.21 & 3.86 & 0.813 & 7.23 & $Y i=820+44.5 X$ & الاسماك \\
\hline$* *$ & 22.70 & 1.77 & 0.654 & 4.76 & $Y i=8282+169 X$ & 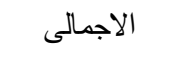 \\
\hline
\end{tabular}

المصدر : حسبت من جدول رقم (3) ..

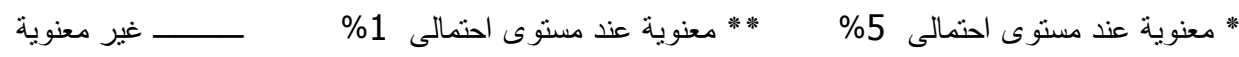


3- تطور متوسط نصيب الفرد من البروتين الحيوانى خلال القترة (2013-2000):

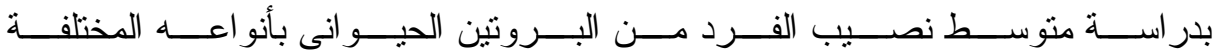

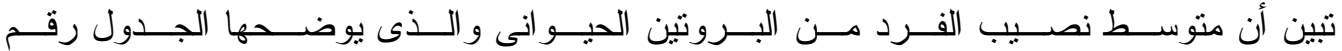

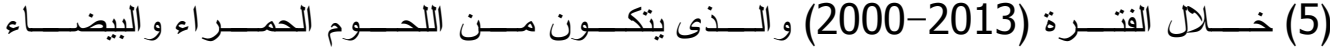

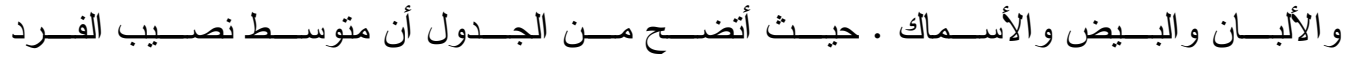

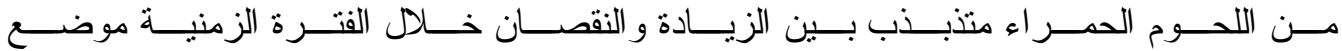

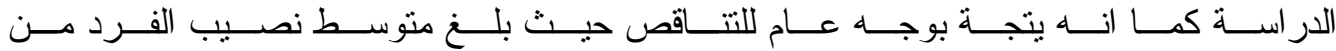

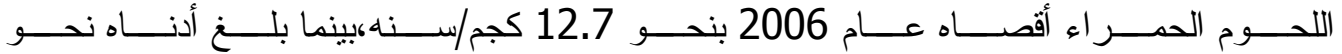

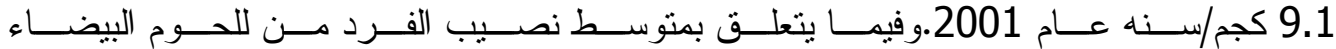

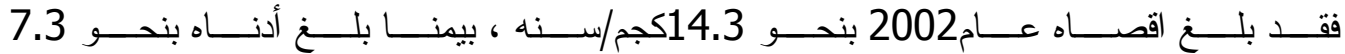

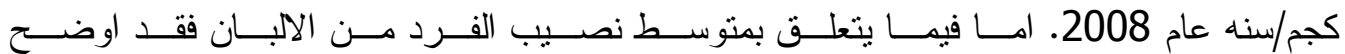

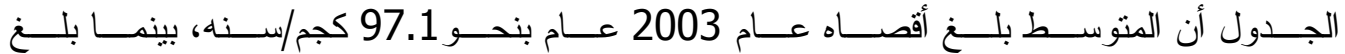

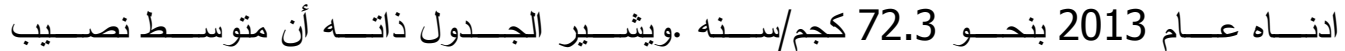

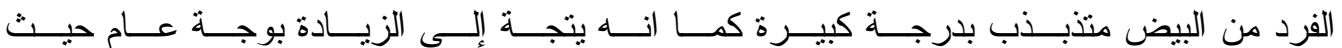

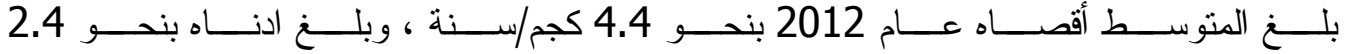

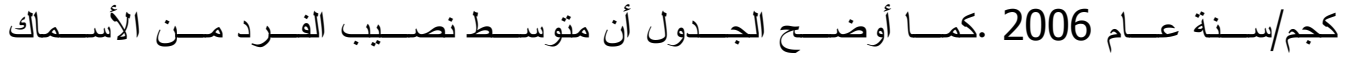

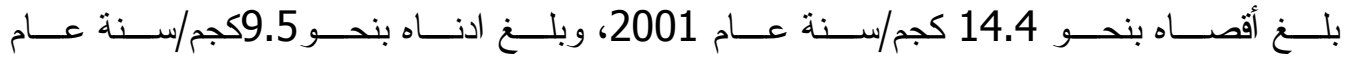

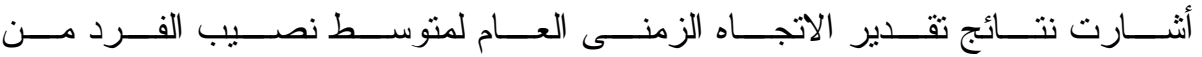

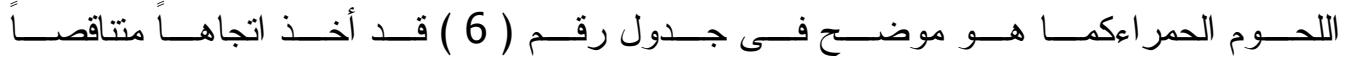

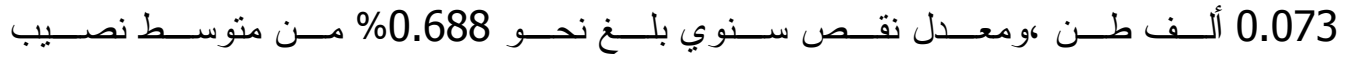

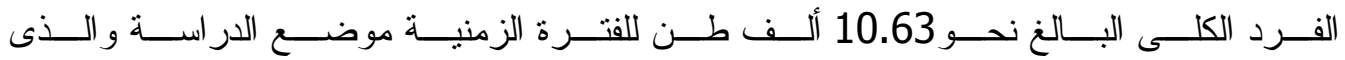

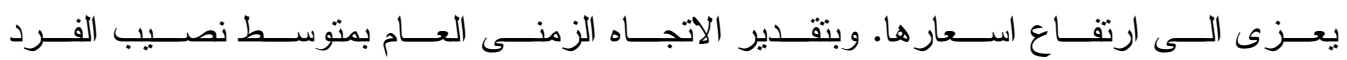

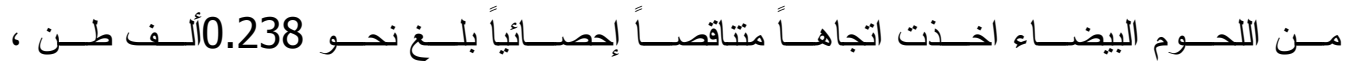

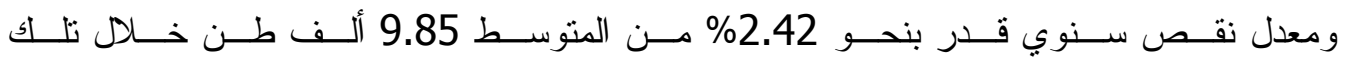

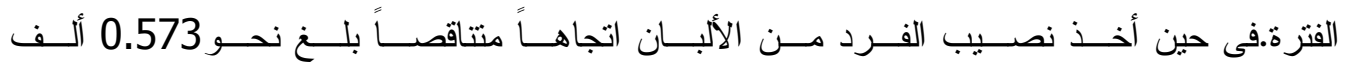

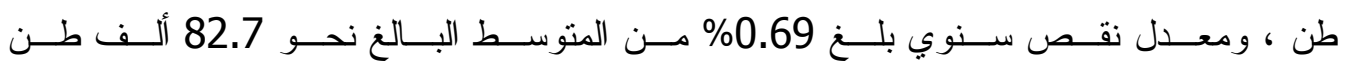

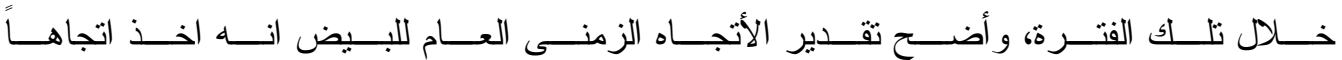

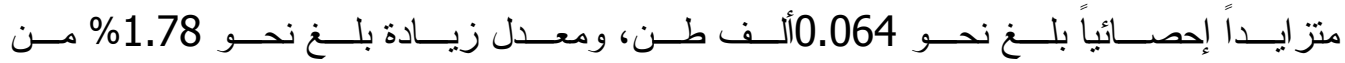

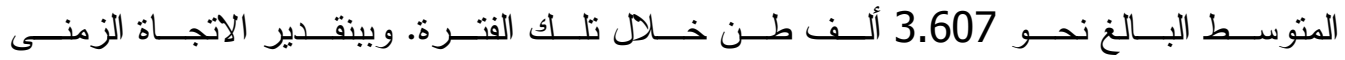

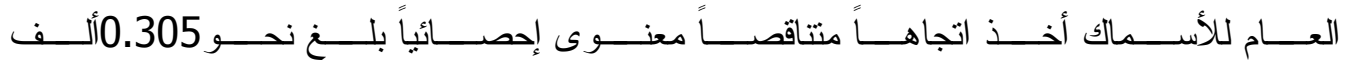

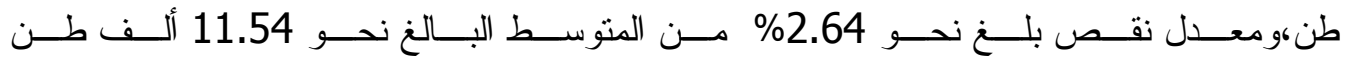
بالفترة موضع الدراسة. 
جدول رقم ( 5) متوسط نصيب الفرد من البروتين الحيو انى خلال الفترة (2013-2000)

\begin{tabular}{|c|c|c|c|c|c|}
\hline متوسط نصيب الفرد من & الفرد من البيض نصيب & الفرد من الألبان & الفرد من اللحوم & متوسط نصيب & \\
\hline 13.4 & 3.1 & 77.5 & 8.7 & 11 & 2000 \\
\hline 14.4 & 3.4 & 79.6 & 11.1 & 9.1 & 2001 \\
\hline 12.5 & 4.0 & 80.7 & 14.3 & 10.5 & 2002 \\
\hline 13.4 & 3.8 & 97.1 & 12.9 & 11.2 & 2003 \\
\hline 12.5 & 3.9 & 78.0 & 11.8 & 10.4 & 2004 \\
\hline 12.8 & 3.1 & 92.8 & 10.7 & 11.1 & 2005 \\
\hline 10.1 & 2.4 & 88.7 & 7.8 & 12.7 & 2006 \\
\hline 10.3 & 2.9 & 91.1 & 8.3 & 13 & 2007 \\
\hline 9.5 & 3.5 & 89.1 & 7.3 & 10.9 & 2008 \\
\hline 9.7 & 3.5 & 79.3 & 8.1 & 10.9 & 2009 \\
\hline 11.6 & 4.1 & 78.4 & 8.6 & 9.8 & 2010 \\
\hline 11.2 & 4.1 & 78.8 & 8.9 & 9.4 & 2011 \\
\hline 10.3 & 4.4 & 75.7 & 9.1 & 9.2 & 2012 \\
\hline 9.9 & 4.3 & 72.3 & 10.3 & 9.7 & 2013 \\
\hline 11.54 & 3.60 & 82.8 & 9.85 & 10.63 & المتوسط \\
\hline
\end{tabular}

المصدر : وزارة الزر اعة واستصلاح الأر اضى ، قطاع الشئون الأقتصادية،شرة الميزان الغذائى - اعداد متفرقة

جدول رقم (6) تقدير الاتجاه الزمني العام لمتوسط نصيب الفرد من اللحوم الحمر اء

و البيضاء و الألبان و البيض و الأسماك

\begin{tabular}{|c|c|c|c|c|c|c|}
\hline المغوية & $\mathbf{F}$ & التغير\% & $\mathbf{R}^{2}$ & $\mathbf{T}$ & المعادلة & البيان \\
\hline _- & 0.86 & 0.668 & 0.067 & -0.93 & $Y i=11.2-0.0732 X$ & اللحوم الحمر اء \\
\hline - & 3.58 & 2.42 & 0.230 & -1.89 & $Y i=11.6-0.238 X$ & اللحوم البيضاء \\
\hline - & 1.38 & 0.69 & 0.103 & -1.18 & $Y i=87.1-0.573 X$ & الألبان \\
\hline _- & 3.27 & 1.78 & 0.214 & 1.81 & $Y i=3.12+0.0644 X$ & البيض \\
\hline *** & 19.60 & 2.64 & 0.620 & -4.43 & $Y i=13.8-0.305 X$ & الاسماك \\
\hline
\end{tabular}

المصدر : حسبت من جدول رقم (5).

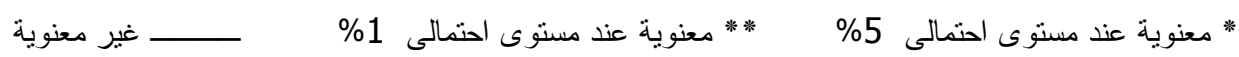

4- تطور الفجوة الغذائية من البروتين الحيوانى خلال الفترة (2013-2000):

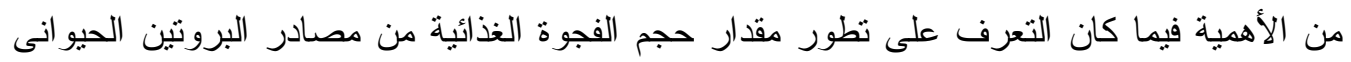

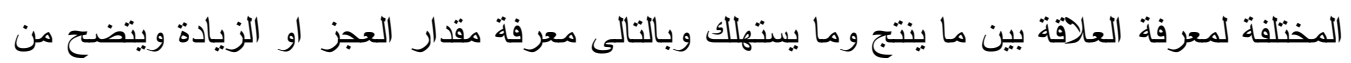
بيانات الجدول رقم (7) الخاص بالفجوة الغذائية للبروتين الحيوانى بكل مكوناته خلال الفترة

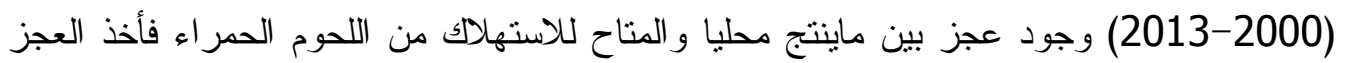
اتجاهاً منذبذباً وقد بلغ العجز اقصاه عام 2007 بنحو 465 ألف طن و أدناه بنحو 97 وألف طن عام 2001 ، اما بالنسبة للحوم البيضاء يتضح لنا وجود عجز بين ماينتج محليا والمتاح للاستهلاك بداء لهاء

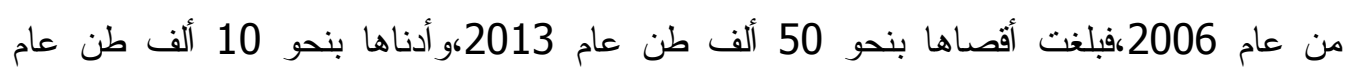
2006 ، فى حين كان هناك فائض فى الانتاج من سنة (2005-2000). فى حين اوضح الجدول

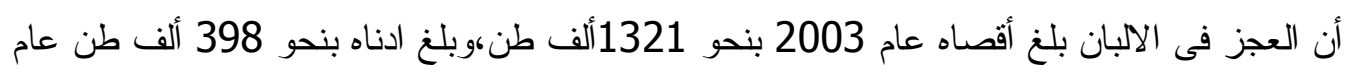


2010 ـ وبالنسبة للبيض وجد أقصي فائض فى عام 2008 بنحو 69 الف طن ، وأدنى فائض بنحو

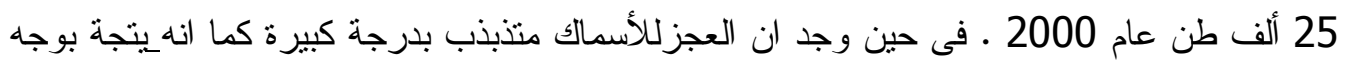

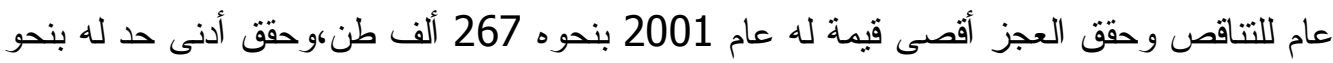
14 الف طن عام 2008 ـ 200

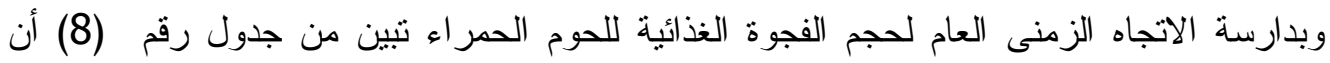

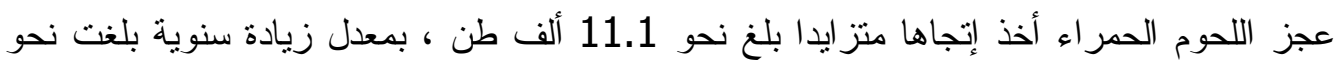

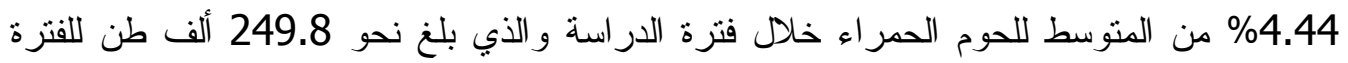

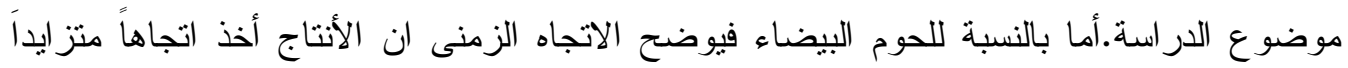

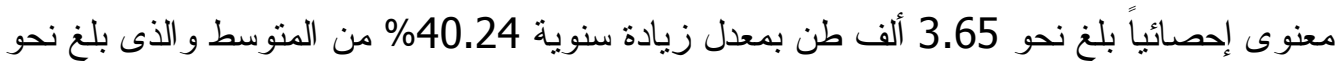

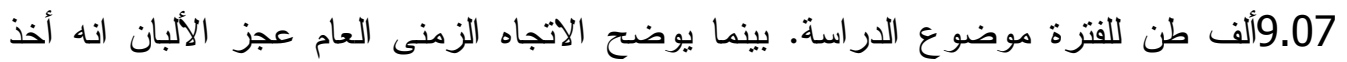

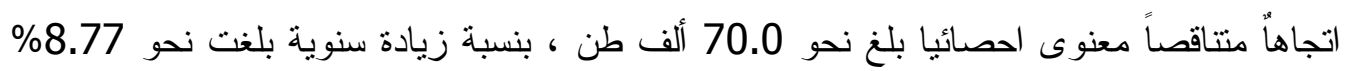

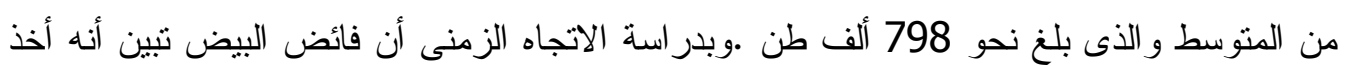

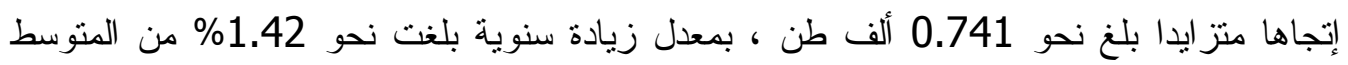

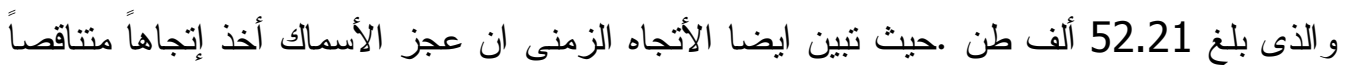

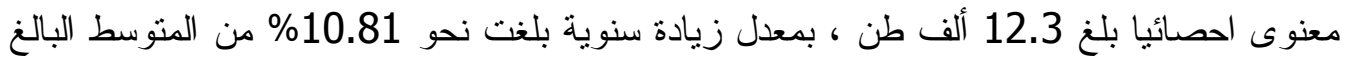

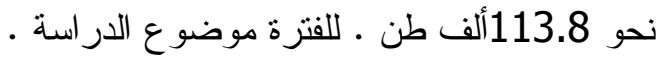

جدول رقم (7) حجم الفجوة الغذائية من البروتين الحيو انى خلال الفترة (2013-2000)

\begin{tabular}{|c|c|c|c|c|c|}
\hline الغذائة الفجوة & الغذائية من الفوة & الغذائية من الفجوة & اللحوم البيضاء النفاء & 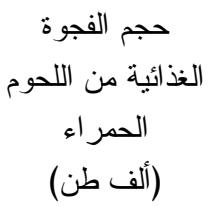 & البيان \\
\hline 224- & 25 & 1137- & 0 & $226-$ & 2000 \\
\hline $267-$ & 45 & $1244-$ & 3 & 97- & 2001 \\
\hline $142-$ & 62 & 1273- & 3 & $139-$ & 2002 \\
\hline 133- & 60 & 1321- & 1 & $179-$ & 2003 \\
\hline 93- & 61 & $725-$ & 0 & $142-$ & 2004 \\
\hline $114-$ & 49 & $1006-$ & 2 & $278-$ & 2005 \\
\hline $129-$ & 56 & $602-$ & $10-$ & $433-$ & 2006 \\
\hline $136-$ & 50 & $782-$ & $3-$ & $465-$ & 2007 \\
\hline $14-$ & 69 & 719- & 41 & $215-$ & 2008 \\
\hline $38-$ & 43 & $469-$ & $20-$ & $215-$ & 2009 \\
\hline 93- & 44 & $398-$ & $25-$ & $261-$ & 2010 \\
\hline $19-$ & 49 & $534-$ & $34-$ & $246-$ & 2011 \\
\hline $146-$ & 56 & $399-$ & $35-$ & $264-$ & 2012 \\
\hline $45-$ & 62 & 563- & $50-$ & $338-$ & 2013 \\
\hline $113.78^{-}$ & 52.21 & 798- & 9.07- & 249.85- & المتوسط \\
\hline
\end{tabular}

المصدر : وزارة الزر اعة واستصلاح الأراضى، قطاع الشئون الأقتصادية،نشرة الميزان الغذائى - اعداد متقرقة 
جدول رقم ( 8 ) تقدير الاتجاه الزمنى العام لحجم الفجوة الغذائية من اللحوم الحمر اء و البيضاء و الالبان و البيض و الاسماك.

\begin{tabular}{|c|c|c|c|c|c|c|}
\hline المغنوية & $\mathbf{F}$ & ا التغير\% & $\mathbf{R}^{2}$ & $\mathbf{T}$ & المعادلة & البيان \\
\hline - & 2.88 & 4.44 & 0.194 & 1.70 & $Y i=167+11.1 X$ & اللحوم الحمر اء \\
\hline *** & 35.80 & 40.24 & 0.749 & 5.98 & $Y i=-11.1+3.65 X$ & اللحوم البيضاء \\
\hline *** & 38.67 & 8.77 & 0.763 & -6.22 & $Y i=1323-70.0 X$ & الألبان \\
\hline _- & 1.01 & 1.42 & 0.077 & 1.00 & $Y i=46.7+0.741 X$ & البيض \\
\hline *** & 12.14 & 10.81 & 0.503 & -3.48 & $Y i=206-12.3 X$ & الاسماك \\
\hline
\end{tabular}

المصدر : حسبت من جدول رقم (7)

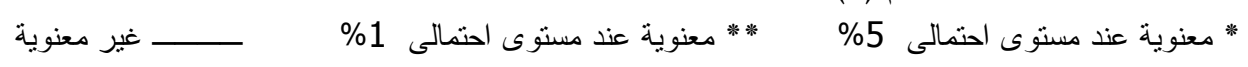

5- تطور نسبة الأكتفاء الذاتى للبروتين الحيوانى خلا الفترة (2013-2000):

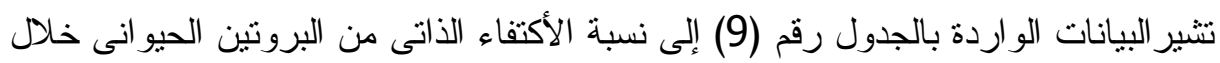

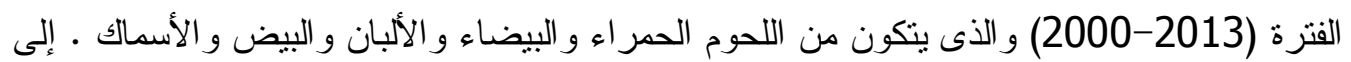

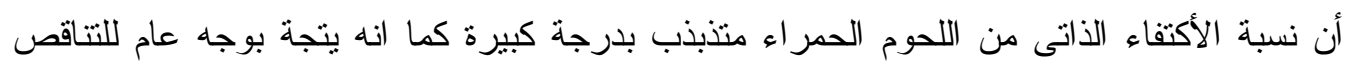
حيث بلغت نسبة الأكتفاء الذاتى من اللحوم الحمر اء أقصاها عام 2001 بنحو 87.8 \% كبينما بلغت أدناها بنحو 67.0 \% عام 2006.وفيما يتعلق بنسبة الأكتفاء الذاتى من اللحوم البيضاءفقد بلغت اقصاها عام 2008 بنحو 105.2\%، بيمنا بلغت أدناها بنحو 69.0\% بأعام 2013.ولقد اوضح

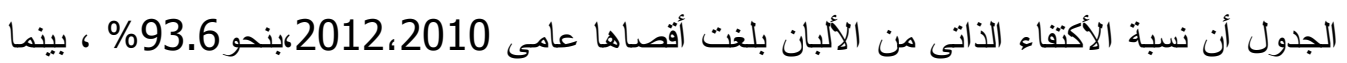

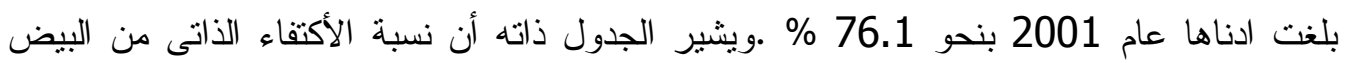

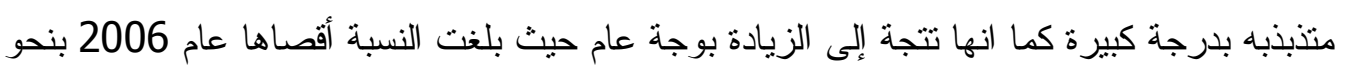
129.8 \% ، وبلغت ادناها بنحو 112.3 \% عام 2000. في كيان حين أوضح

جدول رقم (9) نسبة الأكتفاء الذاتى للبروتنن الحيو انى خلال الفترة (2013-2000)

\begin{tabular}{|c|c|c|c|c|c|}
\hline نسبة الاكتفاء الذاتى & نسبة الأكتناء الذاتى & 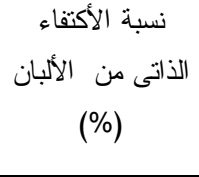 & الذانى من اللفوم البنفاء & 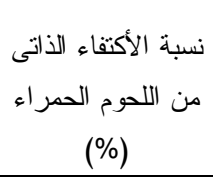 & البيان \\
\hline 76.4 & 112.3 & 77.1 & 100.0 & 75.7 & 2000 \\
\hline 74.3 & 119.9 & 76.1 & 100.3 & 87.8 & 2001 \\
\hline 85.0 & 122.6 & 76.8 & 100.3 & 85.5 & 2002 \\
\hline 86.8 & 122.9 & 80.0 & 100.1 & 82.4 & 2003 \\
\hline 90.3 & 122.3 & 86.6 & 100.0 & 85.2 & 2004 \\
\hline 88.6 & 122.2 & 84.7 & 100.2 & 75.5 & 2005 \\
\hline 88.3 & 129.8 & 90.6 & 98.8 & 67.0 & 2006 \\
\hline 88.1 & 121.8 & 88.3 & 99.7 & 66.4 & 2007 \\
\hline 98.7 & 124.0 & 89.3 & 105.2 & 81.7 & 2008 \\
\hline 96.6 & 114.8 & 92.3 & 97.8 & 82.0 & 2009 \\
\hline 93.3 & 112.4 & 93.6 & 97.4 & 75.2 & 2010 \\
\hline 98.6 & 113.6 & 91.6 & 96.7 & 76.2 & 2011 \\
\hline 90.4 & 113.5 & 93.6 & 96.7 & 74.9 & 2012 \\
\hline 97.0 & 115.2 & 90.8 & 96.0 & 69.8 & 2013 \\
\hline 89.45 & 119.09 & 86.52 & 99.22 & 77.52 & المتوسط \\
\hline
\end{tabular}


الجدول أن نسبة الاكتفاء الذاتى للأسماك بلغت اقصاها بنحو 98.7 \% عام 2008 و أدناها بنحو 74.3 \% عام 2001 ويرجع ذلك للزيادة المضطردة للسكان مع ثبات الانتاج من نلانك

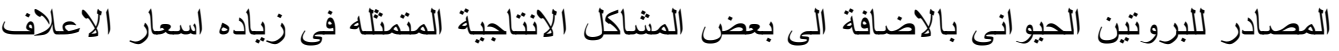

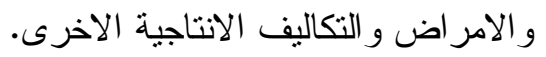

وبدارسة الاتجاه الزمنى العام لنسبة الاكتفاء الذاتى جدول رقم (10) للحوم الحمر اءهاء تبين

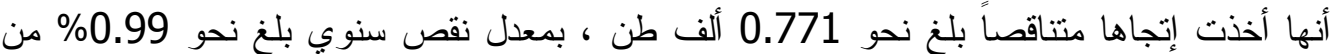

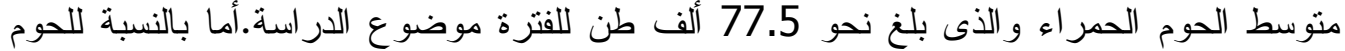

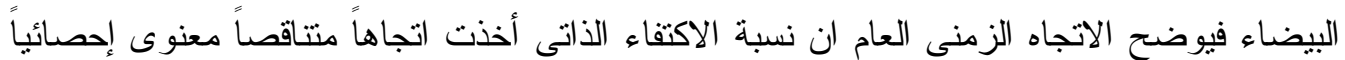

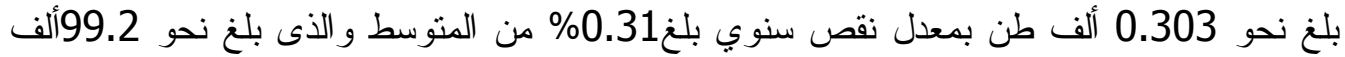

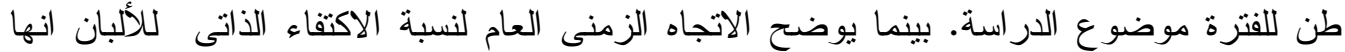

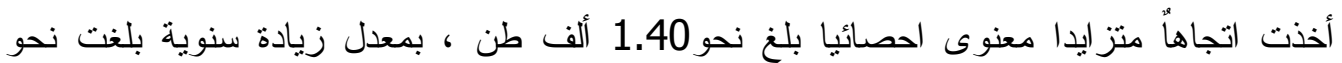
1.62\% من المتوسط و الذى بلغ نحو 86.5 ألف طن .وبدر استة الاتجاه الزمنى العام لنسبة الأكتفاء

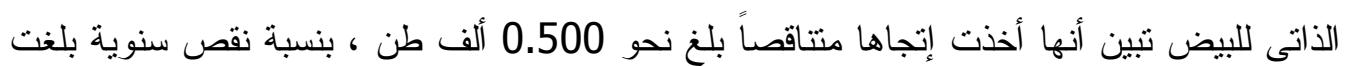
نحو 0.42\% من المنوسط الذى بلغ 119.1ألف طن خلال نلاك الفترة .حيث تبين ايضا أن الأتجاه

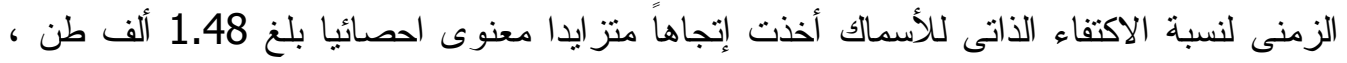

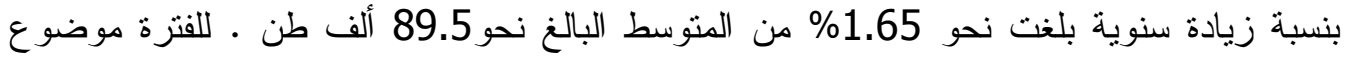

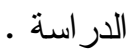

جدول رقم ( 10 ) الاتجاه الزمنى العام للاكثفاء الذاتى من اللحوم الحمر اء و والبيضاء و الالبان و البيض و الاسماك. للاك.

\begin{tabular}{|c|c|c|c|c|c|c|}
\hline المعنوية & $\mathbf{F}$ & التغير\% & $\mathbf{R}^{2}$ & $\mathbf{T}$ & المعادلة & البيان ان \\
\hline- & 3.45 & 0.99 & 0.22 & -1.86 & $Y i=83.3-0.771 X$ & اللحوم الحمر اء \\
\hline$*$ & 5.13 & 0.31 & 0.300 & -2.27 & $Y i=102-0.303 X$ & اللحوم البيضاء \\
\hline *** & 57.13 & 1.62 & 0.826 & 7.56 & $Y i=76.0+1.40 X$ & الألبان \\
\hline 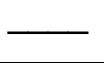 & 2.11 & 0.42 & 0.150 & -1.45 & $Y i=123-0.500 X$ & البيض البي \\
\hline *** & 26.7 & 1.65 & 0.690 & 5.17 & $Y i=78.3+1.48 X$ & الاسماك \\
\hline
\end{tabular}

المصدر : حسبت من جدول رقم (9)

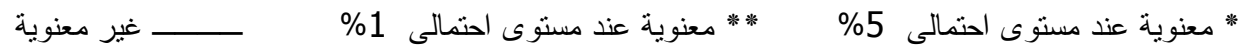

ثانياً : هيكل الأففاق الاستهلاكى لمصادر البروتين الحيوانى بريف وحضر واجمالى الجمهورية وفقاً

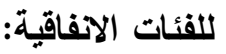

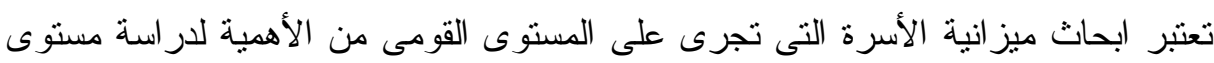

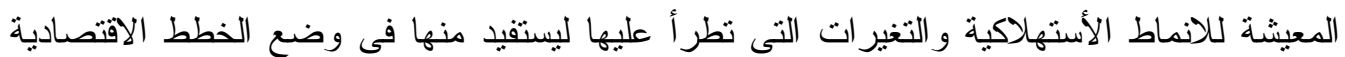

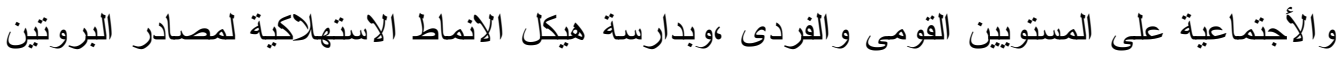


الحيو انى بالريف و الحضر من واقع البيانات الواردة ببحث ميز انية الاسرة 2014 وكما هو موضح

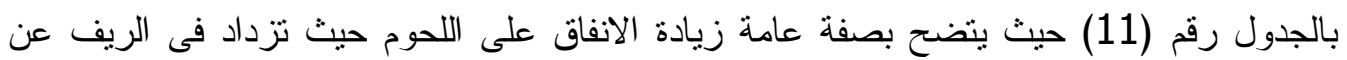

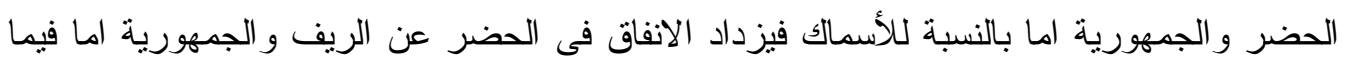

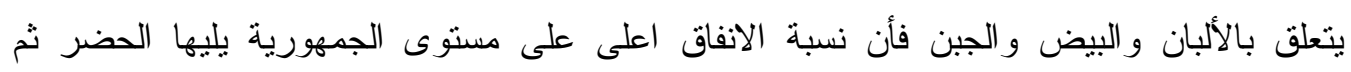
الريف.

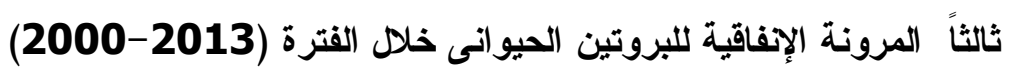
التقدير الإحصائى للمرونات الإنفاقية على مجموعة البروتين الحيوانى فى ريف ريف وحضر

\section{مصر عام 2014.}

تعتبر المرونة الانفاقية اداة تخطيطية هامة تعبر عن استجابة الاستهلاك للتغير ات فى الدخل وتعبر المرونة الإنفاقية عن التغير النسبى فى الإنفاق على سلعة او مجموعة سلعية بالنسبة للتغير

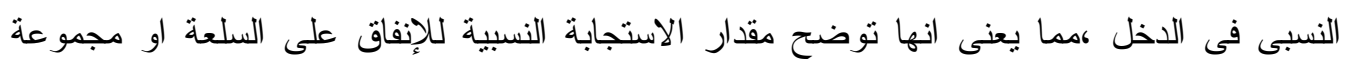

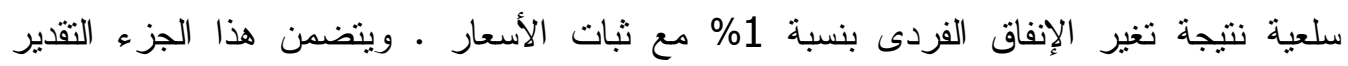

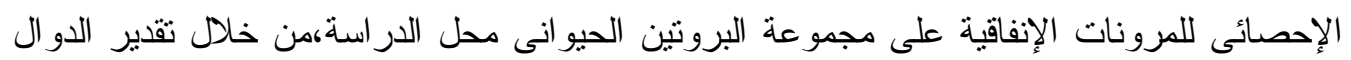
الإنفاقية لهذة المجموعة فى الصورة اللوغارتيمية المزدوجة ، ويمكن من خلال تقدير المرونة الإنة الوقوف على طبيعية التغيرات الهيكلية لأنماط الإنفاق على مجموعة البروتين الحيوانى في رئه ريف

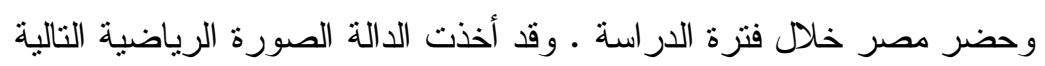
$\log y i=a+b \log x i$

$$
\text { حيث :- }
$$

هog yi-

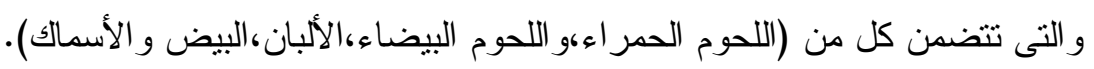
Log xi- لوغارينم إجمالى الأنفاق الفردى السنوى بالجنية.

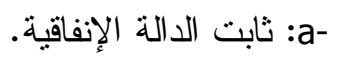

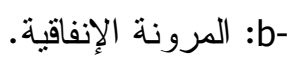

وبتقدير النماذج القياسية للاوال الإنفاقية للمجموعة البروتنن محل الدراسة يتبين من الجدول (8) تثتت معنوية هذه النماذج وفقا للمعايير الإحصائية وذللك لجميع مجموعة البرونين الحيوانى .و أمكن تقدير مرونة الطلب الإنفاقية لتلك المجموعة فى ريف وحضر مصر على النحو التالى: 1- اللحوم : قدرت المرونة الإنفاقية لنلاك المجموعة بنحو 0.59 فى الريف ونفيف ونحو 0.66 فى الحضروعلى مستوى الجمهورية بلغت المرونة الإنفاقية 0.61 ،كما بلغت معاملات التحديد

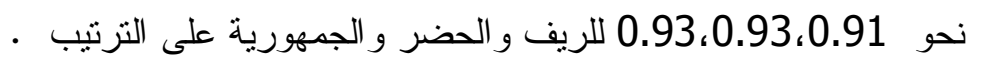

2- الأسماك : بلغت المرونة الأنفاقية لمجموعة الأسماك نحو 0.58 فى الريف ونحو 0.83 فى 0.

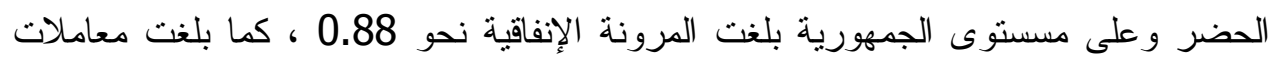
التحديد نحو 0.95 ، 0.93، 0.97، للريف و الحضر و الجمهورية على التزتيب 
3- الألبان و الجبن و البيض : : قدرت المرونة الإنفاقية لتلك المجموعة بنحو 0.49 فى الريف ونحو 0.57 فى الحضروعلى مستوى الجمهورية بلغت المرونة الإنفاقية 0.58 ، كما بلغت معاملات التحديد نحو 0.69 ،0.81، 0.78 للريف و الحضر و الجمهورية على الترتيب . جدول رقم (11) : فئات الانفاق على اللحوم الحمر اء والأسماك و الألبان و الجبن و البيض فى ريف وحضر و إجمالي الجمهورية عام 2014

\begin{tabular}{|c|c|c|c|c|c|c|c|c|c|}
\hline \multirow{2}{*}{ فئات الاففاق } & \multicolumn{3}{|c|}{ الاففاق على اللحوم } & \multicolumn{3}{|c|}{ الانفاق على الاسماك } & \multicolumn{3}{|c|}{ الانفاق على الالبان و الجبن و البيض } \\
\hline & الريف & الحضر & 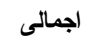 & الريف الريف & الحضر & 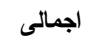 & الريف & 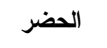 & 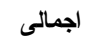 \\
\hline $2000-$ & 896.1 & 622.6 & 729.2 & 67.1 & 92.9 & 82.8 & 1097.2 & 518.2 & 743.9 \\
\hline-2000 & 951.4 & 770.3 & 915.1 & 92.2 & 146.8 & 103.1 & 368.3 & 807.5 & 456.2 \\
\hline-3000 & 687.1 & 845.7 & 741.2 & 106.6 & 66.4 & 92.9 & 379.8 & 241.0 & 332.5 \\
\hline-4000 & 1149.0 & 701.2 & 1034.4 & 100.3 & 117.6 & 104.7 & 321.8 & 485.5 & 363.7 \\
\hline-5000 & 1009.7 & 1251.7 & 1090.3 & 116.8 & 168.7 & 134.1 & 334.9 & 619.3 & 429.7 \\
\hline-6000 & 1061.8 & 869.7 & 993.6 & 162.8 & 161.9 & 162.5 & 380.4 & 544.6 & 438.7 \\
\hline-7000 & 1240.8 & 891.6 & 1104.1 & 178.3 & 192.0 & 183.7 & 414.7 & 589.0 & 482.9 \\
\hline-8000 & 1299.6 & 1094.9 & 1229.9 & 233.7 & 261.5 & 243.2 & 495.8 & 581.6 & 525.0 \\
\hline-9000 & 1430.2 & 1258.5 & 1362.7 & 210.2 & 288.4 & 240.9 & 506.0 & 647.7 & 561.7 \\
\hline-10000 & 1553.4 & 1271.5 & 1458.6 & 241.0 & 271.0 & 251.1 & 606.6 & 664.7 & 626.1 \\
\hline-11500 & 1711.2 & 1452.8 & 1614.8 & 261.5 & 342.1 & 291.5 & 619.5 & 792.6 & 684.1 \\
\hline-13000 & 1857.5 & 1658.0 & 1787.3 & 337.0 & 411.2 & 363.1 & 736.3 & 847.6 & 775.4 \\
\hline-15000 & 2096.3 & 1892.1 & 2021.4 & 382.9 & 450.4 & 407.6 & 845.4 & 979.8 & 894.6 \\
\hline-17000 & 2373.3 & 2181.5 & 2300.2 & 486.7 & 505.7 & 494.0 & 957.3 & 1048.3 & 992.0 \\
\hline-20000 & 2732.9 & 2490.0 & 2635.6 & 610.4 & 644.8 & 624.2 & 1147.6 & 1270.2 & 1196.7 \\
\hline-25000 & 3341.5 & 3008.3 & 3186.6 & 703.9 & 790.4 & 744.1 & 1331.6 & 1593.0 & 1453.1 \\
\hline-30000 & 4160.7 & 3907.9 & 4020.7 & 968.2 & 1021.5 & 997.7 & 1596.6 & 1993.6 & 1816.4 \\
\hline-50000 & 5385.4 & 5336.9 & 5350.9 & 1080.8 & 1291.9 & 1230.7 & 1991.0 & 2597.0 & 2421.3 \\
\hline-75000 & 6184.7 & 5935.5 & 5990.7 & 1519.5 & 1589.2 & 1573.8 & 2498.8 & 2968.4 & 2864.5 \\
\hline+100000 & 8816.1 & 7541.3 & 7729.0 & 1503.3 & 1946.9 & 1881.6 & 1993.5 & 3772.9 & 3511.0 \\
\hline
\end{tabular}


جدول رقم (12) المرونة الأنفاقية لمجموعة البروتين الحيو انى فى ريف وحضر واجمالى الجمهورية عام 2014

\begin{tabular}{|c|c|c|c|c|}
\hline المرونة الإنفاقية & $\mathbf{R 2}$ & النموذج المقدر & صورة النموذج & البروتينات \\
\hline 0.59 & 0.91 & $\begin{array}{r}\log y i=0.883+0.590 \log x i \\
(0.955)\end{array}$ & ريف & \multirow{3}{*}{ 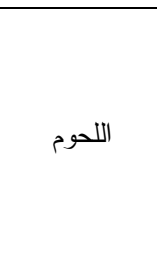 } \\
\hline 0.66 & 0.93 & $\begin{array}{r}\log y i=0.511+0.668 \log x i \\
(15.66)\end{array}$ & حضر & \\
\hline 0.61 & 0.93 & $\begin{array}{r}\log y i=0.776+0.612 \log x i \\
(15.64)\end{array}$ & الجمهورية & \\
\hline 0.85 & 0.95 & $\begin{array}{r}\log y i=-0.0972+0.850 \text { Log } x i \\
(20.65)\end{array}$ & ريف & \multirow{3}{*}{ الأسماك } \\
\hline 0.83 & 0.93 & $\begin{array}{r}\text { Log yi }=-0.840+0.833 \text { Log } x i \\
(15.45)\end{array}$ & حضر & \\
\hline 0.87 & 0.97 & $\begin{array}{r}\log y i=-1.043+0.877 \log x i \\
(24.30)\end{array}$ & الجمهورية & \\
\hline 0.49 & 0.69 & $\begin{array}{c}\log y i=0.872+0.494 \log x i \\
(6.54)\end{array}$ & ريف & \multirow{3}{*}{ الألبان و الجبن } \\
\hline 0.56 & 0.81 & $\begin{array}{c}\log y i=0.652+0.569 \log x i \\
(6.54)\end{array}$ & حضر & \\
\hline 0.57 & 0.78 & $\begin{array}{r}\text { Log } y i=0.573+0.579 \log x i \\
(8.036)\end{array}$ & الجمهورية & \\
\hline
\end{tabular}

المصدر : حسبت من بيانات الجدول رقم (7) 0.01000

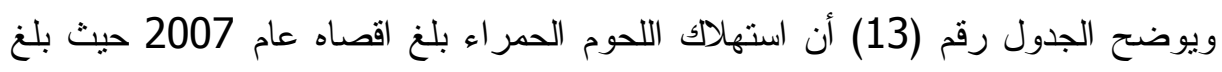
نحو 1382 الف طن ،و أدناه بلغ نحو 793 ألف طن عام 2001 ـ فى حين بلغ أقصى استهلاك للحوم البيضاء عام 2013 بنحو 1237 ألف طن ، و أدنى استهلاك نحو 669 ألف طن طن عام

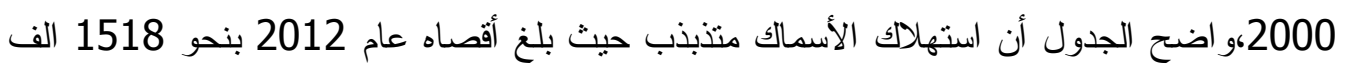

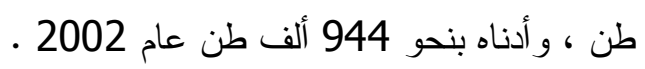
فى حين يوضح الجدول ذاتة أن اسعار اللحوم الحمراء (الجاموسى ، البقرى، الضان) فى تز ايد

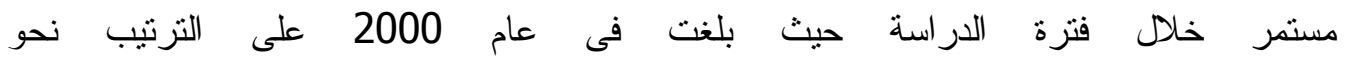

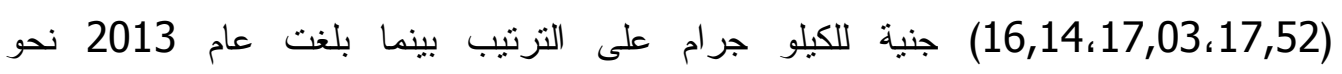
(65,30،67,15،70,77)، جنية للكيلو جرام كما يشير الجدول أن أسعار اللحوم البيضاء (الدجاج

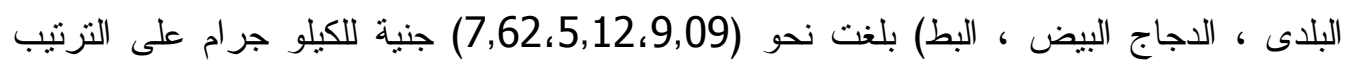

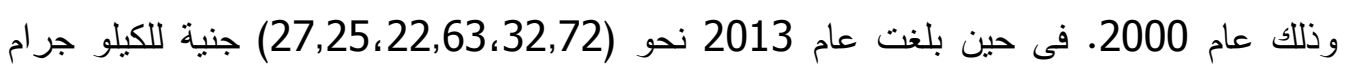
على الترتيب .ويبين الجدول أن أسعار الأسماك (بياض، بلطى ، بورى، قراميط) ايضا فى ارتفاع

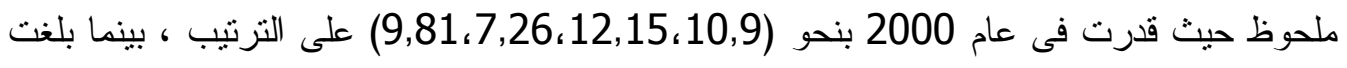

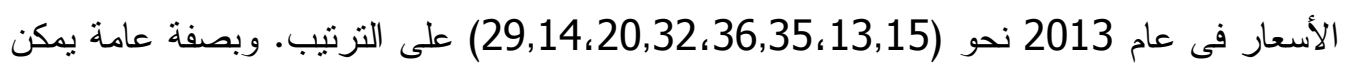

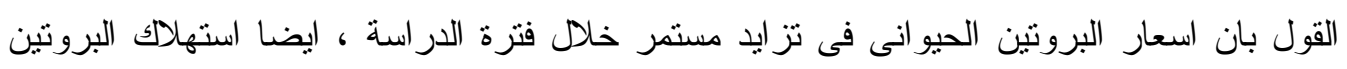

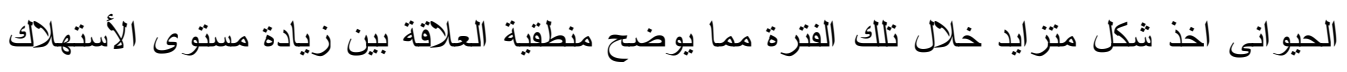

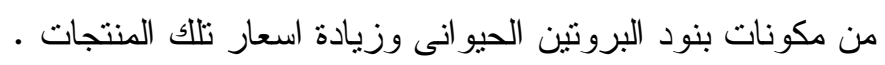


جنية/كجم

جدول (13) استهلاك وأسعار البروتين الحيو انى خلال الفترة (2013-2000)

\begin{tabular}{|c|c|c|c|c|c|c|c|c|c|c|c|c|c|}
\hline أسعار & أسعار & أسعار & البياض اسعار & الأسماك & أسعار البط & الألساج & ألبار البلاى & اللحوم البيضاء & ألسعار & ألبعوم البعرى & ألجام ألجعار & الستهلاك & البيان \\
\hline 10.9 & 12.15 & 7.26 & 9.81 & 948 & 9.09 & 5.12 & 7.62 & 669 & 17.52 & 17.03 & 16.41 & 931 & 2000 \\
\hline 6.46 & 13.90 & 7.38 & 10.06 & 1039 & 9.34 & 5.31 & 7.97 & 860 & 17.72 & 17.12 & 16.44 & 793 & 2001 \\
\hline 6.67 & 14.45 & 7.47 & 10.69 & 944 & 9.45 & 5.76 & 7.91 & 1161 & 18.53 & 18.03 & 17.26 & 960 & 2002 \\
\hline 6.68 & 13.40 & 8.38 & 10.84 & 1009 & 10.99 & 6.44 & 7.95 & 1047 & 22.50 & 20.84 & 19.92 & 1019 & 2003 \\
\hline 7.35 & 14.36 & 10.02 & 14.67 & 958 & 13.90 & 8.07 & 9.31 & 983 & 27.79 & 24.51 & 24.07 & 960 & 2004 \\
\hline 6.98 & 14.58 & 8.61 & 14.69 & 1003 & 14.31 & 7.30 & 8.82 & 1016 & 29.70 & 26.86 & 25.36 & 1133 & 2005 \\
\hline 7.00 & 16.51 & 9.50 & 14.79 & 1100 & 14.34 & 8.37 & 10.28 & 805 & 31.43 & 29.37 & 28.23 & 1312 & 2006 \\
\hline 7.72 & 17.82 & 10.86 & 16.39 & 1144 & 15.92 & 8.61 & 11.23 & 882 & 31.48 & 32.85 & 31.73 & 1382 & 2007 \\
\hline 8.48 & 19.95 & 10.81 & 18.50 & 1082 & 18.57 & 11.94 & 14.45 & 793 & 37.59 & 36.26 & 33.47 & 1176 & 2008 \\
\hline 8.75 & 26.25 & 12.01 & 19.67 & 1131 & 21.67 & 12.01 & 15.66 & 898 & 40.89 & 40.48 & 37.88 & 1196 & 2009 \\
\hline 8.66 & 26.60 & 12.26 & 21.51 & 1398 & 25.95 & 14.62 & 17.30 & 974 & 52.12 & 53.73 & 49.05 & 1052 & 2010 \\
\hline 10.04 & 28.10 & 14.02 & 23.18 & 1381 & 26.14 & 16.63 & 18.50 & 1035 & 59.15 & 58.60 & 57.19 & 1033 & 2011 \\
\hline 11.77 & 3.201 & 17.34 & 24.95 & 1518 & 29.03 & 20.36 & 21.39 & 1072 & 62.69 & 62.90 & 60.88 & 1052 & 2012 \\
\hline 13.15 & 36.35 & 20.32 & 29.14 & 1499 & 32.72 & 22.63 & 27.25 & 1237 & 70.77 & 67.15 & 65.30 & 1118 & 2013 \\
\hline 8.61 & 18.40 & 11.16 & 17.6 & 1153.8 & 17.95 & 10.94 & 13.26 & 959.42 & 37.13 & 36.12 & 34.51 & 1079.7 & الد \\
\hline
\end{tabular}

المصدر: الجهاز المركزى للتعبئة العامة و الاحصاء - نشر ات استهلاك و نشر ات اسعار السلع الغذائية- اعداد منقرقة. 
رابعاً : المرونات السعرية لمجموعة البروتين الحيوانى

تعريف المرونة السعرية:

المرونة السعرية = ( التغير النسبى فى الاستهلاك الفردى السنوى ) / ( التغير النسبى فى سعر

100 x (التجزئة)

فاذا كانت قيمة معامل المرونة سالبة كانت السلعتان متكاملتين و اذا كانت قيمة المعامل

موجبة كانت منبادلتين ، أما اذا كانت مساوية للصفر كانت السلعتين مستقلتين .

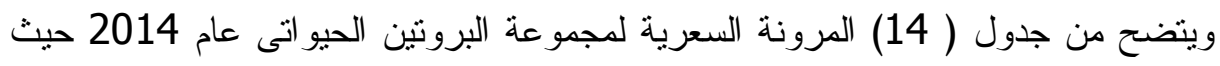

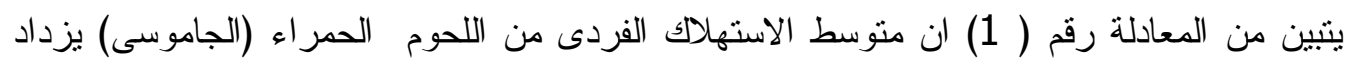

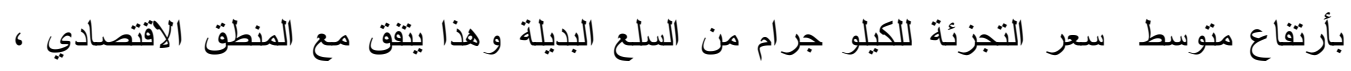
وغير مؤكدا إحصائيا ، وان 34\% من التغيرات فى متوسط الاستهلاك الفردى السنوى ترجع الى سلى

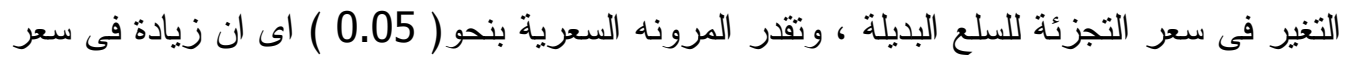

التجزئة للسلع البديلة بمقدار 1\% يؤدى الى زيادة متوسط استهلاكى الفرد بمقدار 0.05 ـ

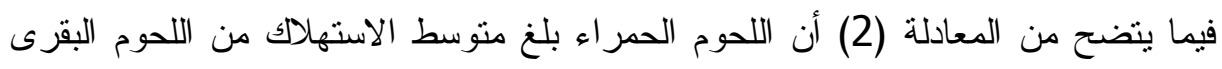

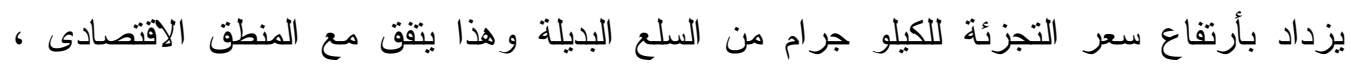

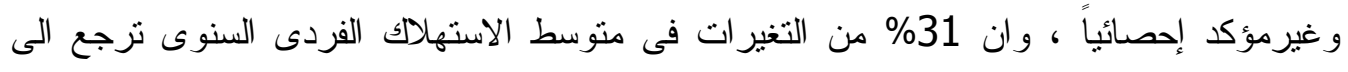

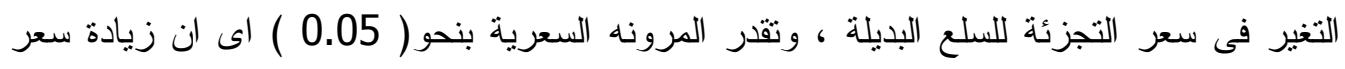
التجزئة للسلع البديلة بقدار 1\% يؤدى الى زيادة منوسط استهلاك الفرد بمقدار 0.05 . جدول رقم (14) المرونة السعرية لمجموعة البروتين الحيو اتى عام 2014

\begin{tabular}{|c|c|c|c|c|c|c|}
\hline المعنوية & المعرية & $\mathbf{R 2}$ & النموذج المقدر & النموذج & رقم المعادلة & 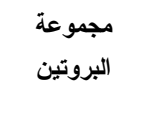 \\
\hline- & 0.05 & 0.34 & $\begin{array}{c}\log y=2.85+0.050 \log x \\
(0.65)\end{array}$ & الجاموس & 1 & \multirow{3}{*}{ اللحوم الحمر اء } \\
\hline- & 0.05 & 0.31 & $\begin{array}{c}\log y=2.85+0.50 \log X \\
(0.62)\end{array}$ & لحوم بقرى & 2 & \\
\hline- & 0.06 & 0.34 & $\log y=2.81+\underset{(0.74)}{0.06 \log x}$ & 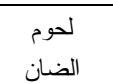 & 3 & \\
\hline - & 0.15 & 0.11 & $\log y=2.50+\underset{(1.23)}{0.15 \log X}$ & دجاج بلدى & 4 & \multirow{3}{*}{ اللحوم البيضـاء } \\
\hline ** & 0.18 & 0.23 & $\log y=2.43+\underset{(1.94)}{0.18 \log x}$ & ابيض & 5 & \\
\hline *** & 0.15 & 0.12 & $\log y=2.47+\underset{(1.28)}{0.15 \log X}$ & البط & 6 & \\
\hline ** & 0.55 & 0.84 & $\log y=1.38+\underset{(8.00)}{0.55 \log X}$ & بلطى بل & 7 & \multirow{3}{*}{ الأسماك } \\
\hline$* *$ & 0.44 & 0.84 & $\log y=1.59+\underset{(8.21)}{0.44 \log X}$ & بورى & 8 & \\
\hline$*$ & 0.15 & 0.30 & $\log y=2.61+\underset{(2.28)}{0.15 \log X}$ & قر اميط & 9 & \\
\hline
\end{tabular}

المصدر :- حسبت من بيانات جدول رقم (13)

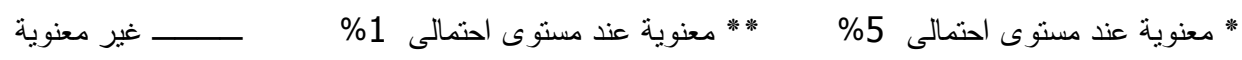


فى حين توضح المعادلة (3) والخاصة باللحوم الحمر اء (الضان)ان متوسط الاستهلالك من اللحوم الضان يزداد بأرتفاع سعر التجزئة للكيلو جرام من السلع البديلة وهذا يتفق مع المنطق الاقتصادى ، و غيرمؤكدا احصائيا ، وان 34\% من التغيرات فى متوسط الاستهلاك الفردى السنوى للحوم الضأن ترجع الى التغير فى سعر التجزئة للسلع البديلة ، وتقدر المرونه السعرية بنحو (0.06) اى ان زيادة سعر التجزئة للسلع البديلة بقدار 1\% يؤدى الى زيادة متوسط استهلاك الفرد بمقدار

وتبين المعادلة (4) والخاصة باللحوم البيضاء (الدجاج البلاى) ان منوسط الاستهلالك من الدجاج البلدى يزداد بأرتفاع سعر التجزئة للكيلو جرام من السلع البديلة وهذا يتقق مع المنطق الاقتصادى ، و غيرمؤكدا احصائيا ، وان 11\% من التغير ات فى منوسط الاستهلاك الفردى السنوى من الدجاج البلاى ترجع الى التغير فى سعر التجزئة للسلع البديلة وتقدر المرونه السعرية بنحو (0.15) اى ان زيادة سعر التجزئة بمقدار 1\% يؤدى الى زيادة متوسط استهالك الفرد بمقدار

وتثير المعادلة (5) و الخاصة بالدجاج الابيض ان متوسط الاستهلاك من الدجاج الابيض

يزداد بأرتفاع سعر التجزئة للكيلو جرام من السلع البديلة وهذا يتفق مع المنطق الاقتصادى ، وهذا التز ايد مؤكدا احصائيا عند مستوى معنوية 0.05، وان 23\% من التغير ات فى متوسط الاستهلاك الفردى السنوى من الاجاج الأبيض ترجع الى التغير فى سعر التجزئة للسلع البديلة ، وتقدر المرونه

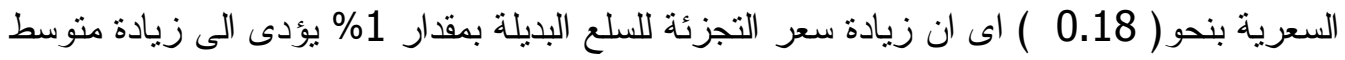
استهلاك الفرد بمقدار 0.18 .

بينما توضح المعادلة (6) فى نفس الجدول و الخاصة باللحوم البيضاء (البط) ان متوسط

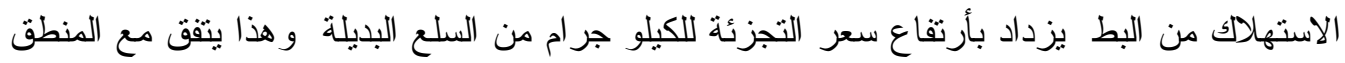

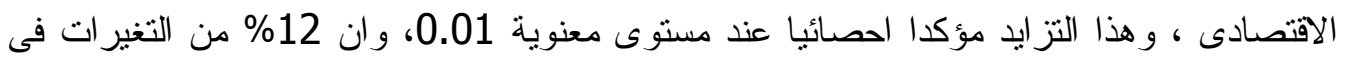
متوسط الاستهلاك الفردى السنوى من البط ترجع الى التغير فى سعر التجزئة للسلع البديلة ، وتقدر

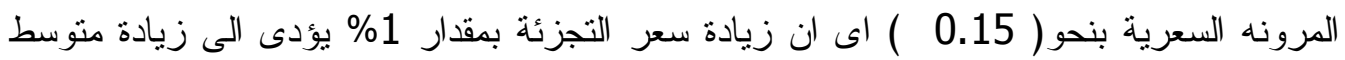
استهلاك الفرد بمقدار 0.15 . وتوضح المعادلة (7) و الخاصة بالأسماك (البلطي) إن منوسط الاستهلاك من البلطى يزداد بأرتفاع سعر التجزئة للكيلو جر ام من السلع البديلة وهذا يتفق مع المنطق الاقتصادى ، و وهذا التزايد مؤكدا احصائيا عند مستوى معنوية 0.01، وان 84\% من التغيرات فى منوسط الاستهلاكى الفردى السنوى ترجع الى التغير فى سعر التجزئة للسلع البديلة ، وتقدر المرونه السعرية بنحو ( ان زيادة سعر التجزئة بمقدار 1\% يؤدى الى زيادة منوسط استهلالك الفرد بمقدار 0.55 ـ ولقد اوضح الجدول ان المعادلة (8) الخاصة بالسمك البورى ان منوسط الاستهالاكك من

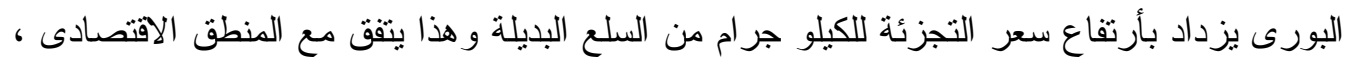

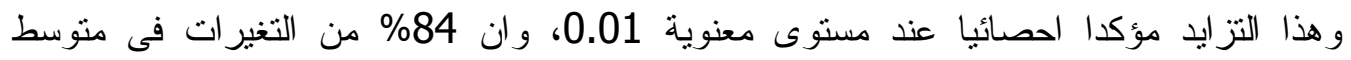
الاستهلاك الفردى السنوى نرجع الى التغير فى سعر التجزئة للسلع البديلة ، وتقدر المرونه السعرية منية 
بنحو ( 0.44 ) اى ان زيادة سعر التجزئة بقدار 1\% يؤدى الى زيادة منوسط استهلاك الفرد بمقدار 0.44

و أخير ا توضح المعادلة (9) الخاصة بالسمك القر اميط ان متوسط الاستهلالك من القراميط

يزداد بأرتفاع سعر التجزئة للكيلو جرام من السلع البديلة وهذا يتفق مع المنطق الاقتصادى ، وهذا التز ايد مؤكدا احصائيا عند مسنوى معنوية 0.05، وان 30\% من التغير ات فى منوسط الاستهلاك الفردى السنوى ترجع الى التغير فى سعر التجزئة للسلع البديلة ، وتقدر المرونه السعرية بنحو(0.15) اى ان زيادة سعر التجزئة بقدار 1\% يؤدى الى زيادة متوسط استهلاك الفرد بمقدار

\section{النتائج و التوصيات}

وقد توصلت الار اسة الى النتائج التالية أولا فيما يتعلق بأنتاج البروتين الحيوانى فقد تنين زيادة انتاج كل من اللحوم الحمراء و اللحوم

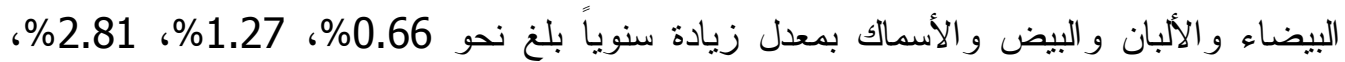
4.44\%، 5.46\%، على التزتيب وقد ثبت معنوية هذه الزيادة لككونات البروتين الحيوانى عند

مستوى معنوية 0.01 ماعدا اللحوم الحمر اء و البيضاء فكانت الزيادة غير معنوية. ثانياً اما بالنسبة للاستهلاك فان معدل التغير السنوي لاستهلاك كل من اللحوم الحمراء و البيضاء

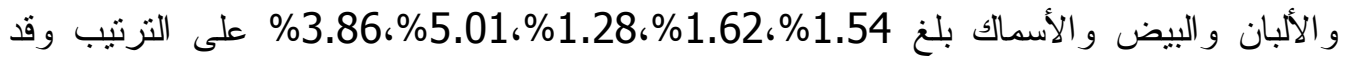

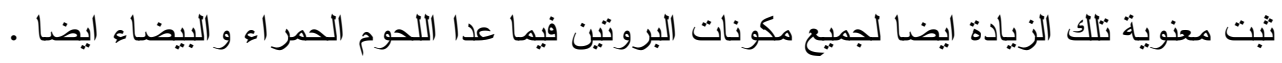

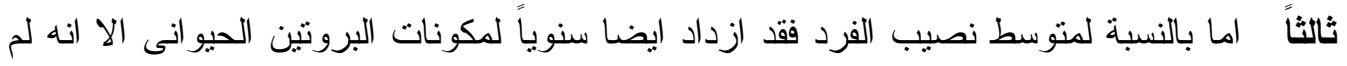
يثبت معنوية هذه الزيادة الا للأسماك فقط ويرجع ذللك للتذبذب فى متوسط نصيب الفرد خلال فترة

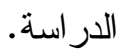
رابعاً اما فيما يتعلق بنسبة الفائض والعجز لمكونات البروتين الحيوانى فقد اتضح وجود عجز فى في

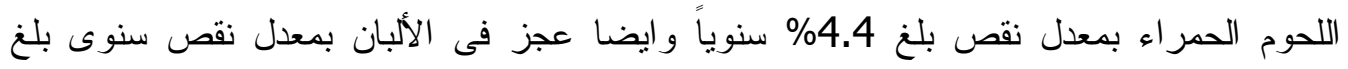
8.7\% ، وكذلك بلغ معدل التغير للعجز فى السماك نحو 10.8\% خلا بل فترة الدر اسة كما أتضح وجود فائض فى كل من البيض و اللحوم البيضاء بمعدل زيادة سنوى بلغ نحو 1.42\% بعل على التزتيب.

خامساً اما بالنسبة للأكتفاء الذاتى من مكونات البروتين الحيو انى فقد اتضح تتاقص نسبة الأكتفاء الذاتى فى كل من اللحوم الحمراء ، واللحوم البيضاء، والبيض بمعدل انخفاض معنوى بلغ نحو

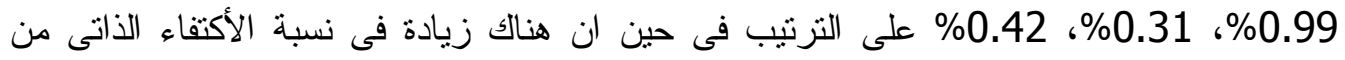

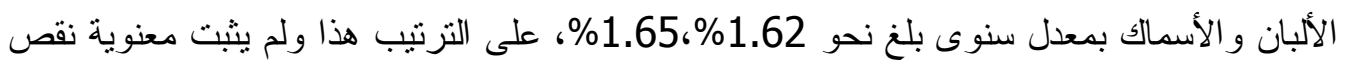

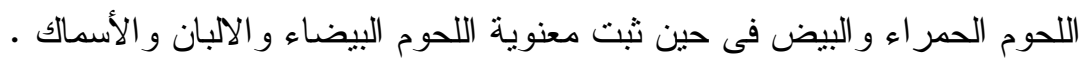

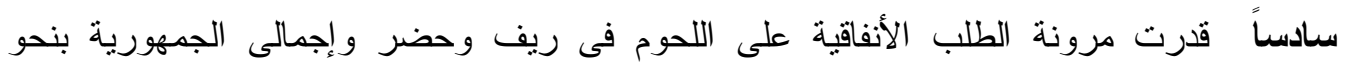

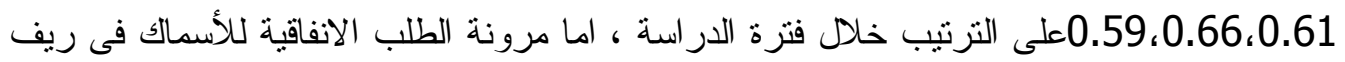
وحضر وإجمالى الجمهورية بلغت 0.85،0.83،0.87على الترتيب فى حين بلغت مرونه الطلب 
الانفاقية على الألبان والبيض والجين نحو 0.57،0.56،0.49 فى الريف والحضر وإجمالى

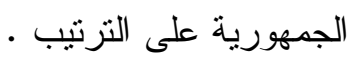

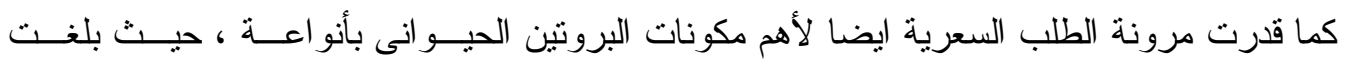

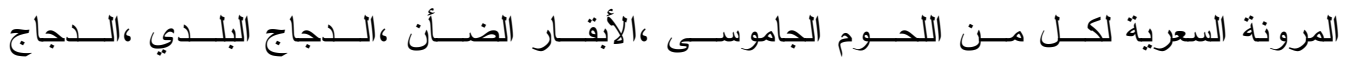

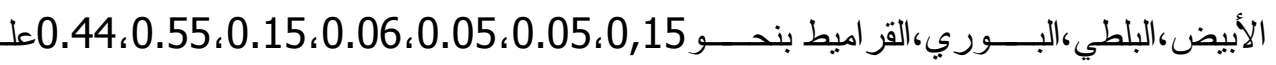

$$
\begin{aligned}
& \text { التزتيب. } \\
& \text { وتأسيساً على ماسبق فإن الدراسة توصى بما يلى :- }
\end{aligned}
$$

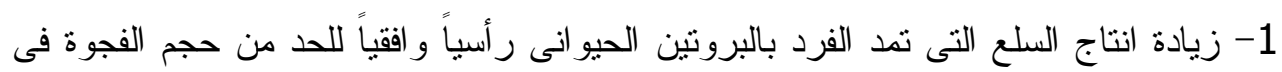

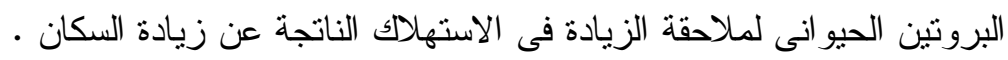

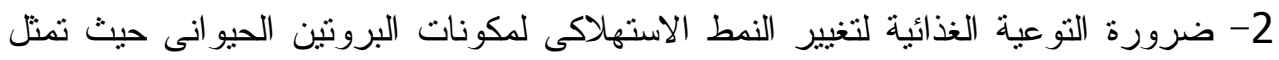

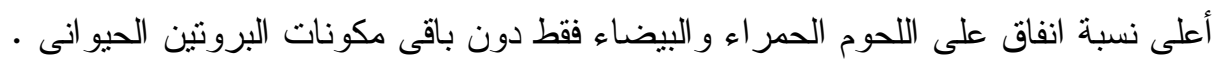

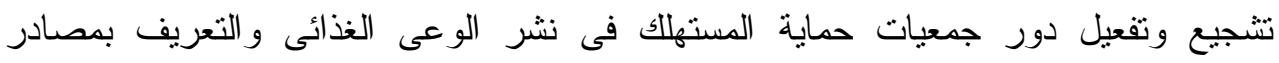

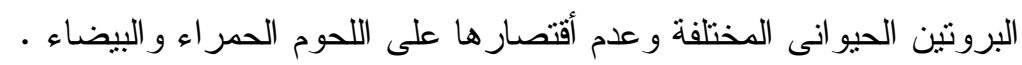

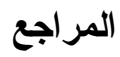

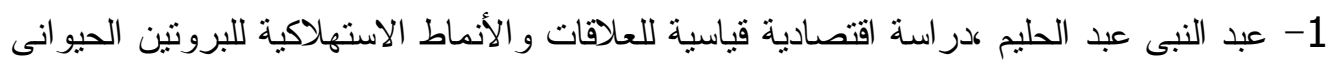

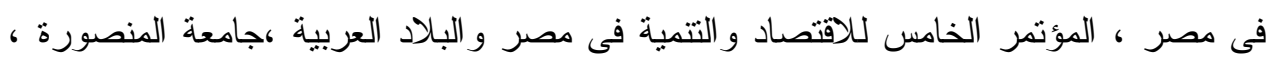
ابريل 1996.

2- شوقى أمين عبد العزيز كدراسة اقتصادية لاستهلاك اللحوم الحمراء فى مصر و أثز الأنفاق

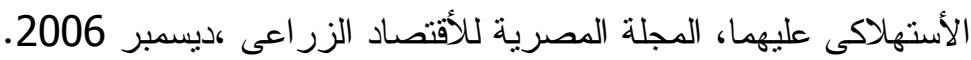

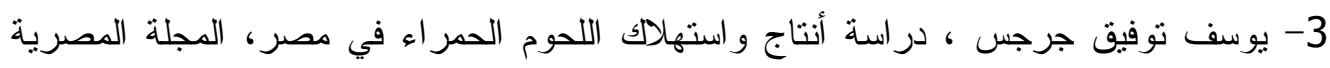

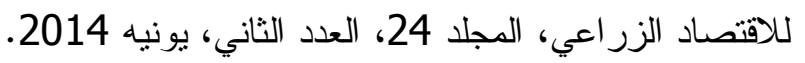

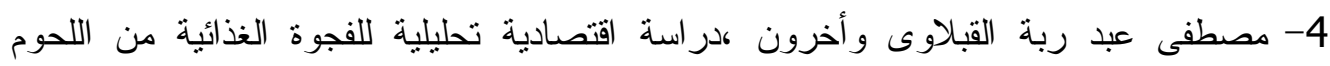
الحمر اء في مصر، المجلة المصرية للاقتصاد الزر اعي ، المؤتمر الثاني و العشرون للأقتصادين

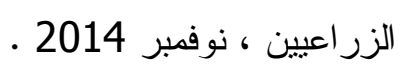

5- احمد احمد السيد، الطلب على البروتين الحيوانى فى ريف محافظة الثرقية، المجلة المصرية

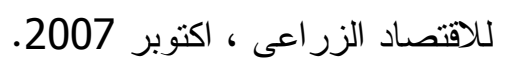

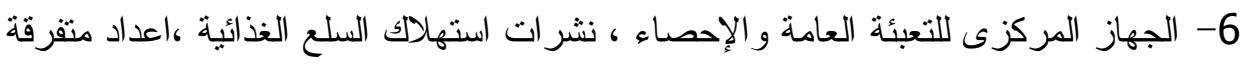

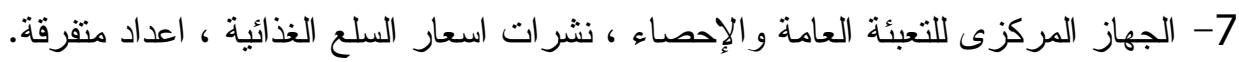
8- الجهاز المركزى للتعبئة العامة والإحصاء ،بحث الإخل الأل و الأنفاق ،2014. 